Submitted, accepted and published in Applied Catalysis B: Environmental 147 (2014) 947-957. Post-print of:

\title{
Towards an optimal synthesis route for the preparation of highly mesoporous carbon xerogel-supported Pt catalysts for the oxygen reduction reaction
}

\author{
C. Alegre ${ }^{1,2}$, M.E. Gálvez ${ }^{1}$, R. Moliner ${ }^{1}$, V. Baglio ${ }^{2, *}$, A.S. Aricò ${ }^{2}$ and M.J. Lázaro ${ }^{1, *}$ \\ ${ }^{1}$ Instituto de Carboquímica (CSIC), Miguel Luesma Castán 4, 50018 Zaragoza, Spain \\ ${ }^{2}$ Istituto di Tecnologie Avanzate per lôEnergia ñNicola Giordanoò, CNR. \\ Via Salita S. Lucia sopra Contesse, 5, 98126, Messina (Italia)
}

*Corresponding authors:

María Jesús Lázaro, Instituto de Carboquímica, CSIC, Miguel Luesma Castán 4, 50018, Zaragoza, Spain. Fax: +34 976733318; Tel: +34 976733977; E-mail: mlazaro@icb.csic.es;

Vincenzo Baglio, Istituto di Tecnologie Avanzate per lâEnergia ñNicola Giordanoò, CNR, Via Salita S. Lucia Sopra Contesse 5, Messina, Italy. Fax: +39 090 624247; Tel: +39090 624237; vincenzo.baglio@itae.cnr.it; 
Submitted, accepted and published in Applied Catalysis B: Environmental 147 (2014) 947-957. Post-print of:

1 Abstract: Pt particles were supported on a highly mesoporous carbon xerogel and used 2 as catalysts for the oxygen reduction reaction (ORR) in Direct Methanol Fuel Cells 3 (DMFCs). Different synthesis routes were followed in order to study their influence on 4 the characteristics and the performance of Pt electrocatalysts, therefore determining the 5 optimal synthesis method for the preparation of these carbon xerogel supported 6 catalysts, leading to the highest catalytic activity. The highest active catalyst was 7 compared to a Pt catalyst supported on commercial carbon support, Vulcan, synthesized 8 in the same conditions. Synthesis methods studied were impregnation, following two 9 different reduction protocols (sodium borohydride and formic acid), and microemulsion, 10 used for the first time for carbon xerogels. The electrochemical characterization proved 11 that the catalystsô synthesis method strongly influenced the catalytic behavior. The impregnation method and reduction with formic acid lead to the highest active catalyst towards ORR. When compared to an analogously prepared Vulcan carbon blacksupported catalyst, the carbon xerogel-based one still showed enhanced performance, in spite of higher ohmic loss, due to the lower electrical conductivity of this carbon material.

Keywords: Pt; catalysts; carbon xerogel; synthesis method; ORR. 
Submitted, accepted and published in Applied Catalysis B: Environmental 147 (2014) 947-957. Post-print of:

\section{Introduction}

The oxygen reduction process is a limiting step in the development of highly efficient low temperature fuel cells, due to the large overpotential needed to achieve high current densities [1]. Due to their intrinsic activity and stability in acidic solutions, $\mathrm{Pt} / \mathrm{C}$ electrocatalysts are, at present, the most widely used materials as cathodes [2] in proton conducting electrolyte-based low temperature fuel cells, such as direct methanol fuel cells (DMFCs), operating with methanol, a liquid fuel presenting great advantages in terms of handling [3]. Nevertheless, there is still great interest in developing more active, selective and less costly electrocatalysts for the oxygen reduction reaction (ORR) [4]. Considerable efforts are being thus made whether to obtain Pt-free catalysts [5], whether to improve the electrocatalytic performance of Pt catalysts [6]. Regarding the first issue, several papers have been published in the last years describing the use of carbonï supported iron-based catalysts with active sites containing iron cations coordinated by pyridinic nitrogen functionalities, which show similar activities to those prepared using $\mathrm{Pt}$ [7-9]. On the other hand, efforts to improve the electrocatalytic performance of Pt catalysts have focused on improving catalytic effectiveness of Pt by dispersing catalyst materials onto an electrode support with high surface area and conducting properties, such as carbon materials and metallic oxides [10-14], or by synthesizing Pt and Pt-based advanced nanomaterials [14], such as core-shell catalysts [15-17].

Regarding the use of carbon supports, it is generally recognized that a high Pt wt. $\%$ on the carbon substrate will significantly decrease the thickness for the same $\mathrm{Pt}$ loading per geometric electrode area. Thus, it is possible to enhance mass transport through the electrode and, at the same time, considerably reduce the ohmic losses. The synthesis of a highly dispersed electrocatalyst phase in conjunction with a high metal loading on carbon support is one of the goals of the recent activity in the field of DMFCs [18]. In this sense, one of the main requirements for an optimal electrocatalyst is its high dispersion. The mass activity $\left(\mathrm{A} \mathrm{g} \mathrm{g}^{-1}\right)$ of the catalyst for an electrochemical reaction is directly related to the degree of dispersion, since the reaction rate is generally proportional to the active surface area [3]. 
Submitted, accepted and published in Applied Catalysis B: Environmental 147 (2014) 947-957. Post-print of:

The success obtaining a highly dispersed catalyst will depend both on the synthesis method and the support. Among the main synthesis routes for the preparation of $\mathrm{Pt} /$ carbon electrocatalysts one can find impregnation, colloidal procedures, selfassembling and Pt decoration methods [3, 19-21]. The strong influence of the catalyst preparation procedure on its properties makes it necessary to optimize each synthesis method, taking into consideration the particular characteristics of the support, in order to obtain a properly dispersed active phase, with the most appropriate crystal size and chemical state.

With respect to the carbon material, and among the various types of carbon supports considered in the last decades, carbon xerogels have been extensively studied and successfully employed in electrochemical applications, due to their unique and easily controllable properties [22, 23]. These materials offer high surface area, mesopore structure with tunable pore size distribution, and high purity. Besides, when used as catalysts supports, their three-dimensionally interconnected uniform pore structure allows a high degree of dispersion of the active phase and an efficient diffusion of reagents [24]. Moreover, several authors have described enhanced performance of catalysts supported on carbon xerogels when compared to conventional supports, such as Vulcan carbon black [25-28].

However, in order to further increase the efficiency of carbon xerogel supported Pt catalysts, it is necessary to develop a simple procedure to obtain Pt catalysts with relatively high metal loading and optimal dispersion [29]. In this work, several synthesis methods have been considered with the aim of determining the optimal procedure to prepare highly active Pt catalysts supported on a highly mesoporous carbon xerogel. As a first screening, a metal loading of a $20 \mathrm{wt} . \%$ has been chosen to analyzed the optimal method, in order to carry on in the future with higher Pt loadings, allowing enhancing mass transport through the electrode and, at the same time, reducing the ohmic drop. Upon the optimization of the synthesis method, the catalytic activity of the carbon xerogel-supported electrocatalyst has been compared to that of an analogously prepared carbon black-supported one, in order to analyze the particular influence of the nature of the carbon support. 
Submitted, accepted and published in Applied Catalysis B: Environmental 147 (2014) 947-957. Post-print of:

82

\section{Experimental details}

\subsection{Synthesis of the carbon xerogel}

CXG was synthesized as described in [31] by the pyrolysis at $800^{\circ} \mathrm{C}$ of an organic gel obtained by the polycondensation of resorcinol and formaldehyde in stoichiometric ratio ( 2 moles of formaldehyde per mole of resorcinol). The gelation and curing process took place at an initial $\mathrm{pH}$ of 6.0 and using sodium carbonate as catalyst $(0.04 \mathrm{~mol} \%$ with respect to total content of resorcinol + formaldehyde). Curing of the organic gel was carried out for $24 \mathrm{~h}$ at room temperature, $24 \mathrm{~h}$ at $50{ }^{\circ} \mathrm{C}$ and $120 \mathrm{~h}$ at $85^{\circ} \mathrm{C}$. Subsequently, remaining water was exchanged with acetone and the gel was dried under subcritical conditions before its pyrolysis. Pyrolysis took place at $800{ }^{\circ} \mathrm{C}$ under a nitrogen atmosphere for $3 \mathrm{~h}$.

\subsection{Synthesis of the Pt-catalysts}

Pt catalysts with a 20 wt. \% loading were synthesized using CXG as support, by means of different synthesis methods. Synthesis routes included: impregnation and reduction with two different reducing agents: sodium borohydride (i-SBM) and formic acid (i-FAM) and a microemulsion based method (ME).

For the impregnation method and reduction with $\mathrm{NaBH}_{4}$, a $3 \mathrm{mM}$ aqueous solution of $\mathrm{H}_{2} \mathrm{PtCl}_{6}$ (Sigma-Aldrich), was slowly added to a dispersion of the $\mathrm{CXG}$ in ultrapure water under sonication. $\mathrm{pH}$ was adjusted to 5 with a $\mathrm{NaOH}$ (Panreac) solution, followed by addition of a $25 \mathrm{mM}$ aqueous solution of $\mathrm{NaBH}_{4}$ (Sigma-Aldrich), maintaining the temperature around $18^{\circ} \mathrm{C}$. The catalyst so obtained was named Pt/CXGi-SBM.

In the case of using formic acid as reducing agent, the carbon material was first dispersed in a $2 \mathrm{M} \mathrm{HCOOH} \mathrm{(Panreac)} \mathrm{solution} \mathrm{at} 80{ }^{\circ} \mathrm{C}$. Subsequently, a $4 \mathrm{mM}$ aqueous solution of the metallic precursor, $\mathrm{H}_{2} \mathrm{PtCl}_{6}$ (Sigma-Aldrich), was added stepwise. The catalyst obtained in such a way was named Pt/CXG-i-FAM. Finally both type of catalysts were filtered and thoroughly washed with ultrapure water, and dried overnight at $60^{\circ} \mathrm{C}$.

Pt nanoparticles were also synthesized by the water in oil microemulsion route (ME) [31], that consists of preparing a microemulsion composed of a commercial surfactant 
Submitted, accepted and published in Applied Catalysis B: Environmental 147 (2014) 947-957. Post-print of:

(Brij30, Sigma-Aldrich), n-heptane as the non-polar phase and 2-propanol as cosurfactant. Briefly, the surfactant and n-heptane were mixed and stirred. An aqueous solution of $\mathrm{H}_{2} \mathrm{PtCl}_{6}(8 \mathrm{mM})$ was then added dropwise. Subsequently, 2-propanol was added until an optically transparent mixture was observed, indicating the formation of the microemulsion. After $4 \mathrm{~h}$ of stirring, the reducing agent $\left(\mathrm{NaBH}_{4}\right)$ was slowly added in $0.1 \mathrm{M}$ aqueous solution to the microemulsion under continuous stirring. The suspension was slowly added to a suspension of CXG in ethanol under sonication. Finally the catalyst was thoroughly washed with ethanol and water and subsequently dried overnight at $60^{\circ} \mathrm{C}$ [32]. The catalyst so obtained was named Pt/CXG-ME.

\subsection{Physico-chemical characterization}

The textural and morphological features of the different carbon supports and catalysts prepared were determined by means of $\mathrm{N}_{2}$ physisorption at $\overline{\mathrm{i}} 196{ }^{\circ} \mathrm{C}$ (Micromeritics ASAP 2020). Specific surface area and pore volume were calculated from such isotherms applying the Brunauer-Emmet-Teller (BET) equation, BarrettJoyner-Halenda (BJH) and t-plot methods. Inductively coupled plasma atomic emission spectroscopy (ICP-AES) was used to determine the amount of metal deposited. Catalysts were as well characterized by X-Ray Diffraction (XRD), using a Bruker AXS D8 Advance diffractometer. Crystallite sizes were calculated from the Scherrerôs equation on the (220) peak for Pt. Particle sizes were evaluated from TEM images obtained in a JEOL $2100 \mathrm{~F}$ microscope operated with an accelerating voltage of $200 \mathrm{kV}$ and equipped with a field emission electron gun providing a point resolution of 0.19 $\mathrm{nm}$. The standard procedure involved dispersing $3 \mathrm{mg}$ of the sample in ethanol in an ultrasonic bath for $15 \mathrm{~min}$. The sample was then placed in a $\mathrm{Cu}$ carbon grid where the liquid phase was evaporated. X-ray photoelectron spectrometry (XPS) analyses were performed using a ESCAPlus Omicron spectrometer equipped with a $\mathrm{Mg}(1253.6 \mathrm{eV})$ anode, $150 \mathrm{~W}(15 \mathrm{~mA}, 10 \mathrm{kV})$ power, over an area of sample of $1.75 \times 2.75 \mathrm{~mm}$. Pt $4 \mathrm{f}$ $(65 \mathrm{I} 84 \mathrm{eV})$ signals were obtained at $0.1 \mathrm{eV}$ step, $0.5 \mathrm{~s}$ dwell and $20 \mathrm{eV}$ pass energy. Spectra were deconvoluted using CasaXPS software. 
Submitted, accepted and published in Applied Catalysis B: Environmental 147 (2014) 947-957. Post-print of:

\subsection{Electrochemical characterization and activity}

Gas diffusion electrodes were prepared according to a procedure described elsewhere [32], consisting of carbon cloth backing, gas diffusion layer and the catalytic layer under study. The membrane electrode assemblies (MEAs) for single cell studies were prepared by hot-bonding the electrodes on either side of a pretreated Nafion-115 membrane at $130^{\circ} \mathrm{C}$. The cathode consisted of the catalyst under study pasted on a hydrophobic backing layer (LT 1200W ELAT, ETEK) with a Pt loading of ca. 0.5 $\mathrm{mg} \cdot \mathrm{cm}^{-2}$. The anode consisted of a commercial PtRu black (1:1 at., Johnson Mattey) pasted on a backing layer (HT ELAT, E-TEK) and with a Nafion content of $15 \%$ wt. The Pt loading was kept to ca. $0.5 \mathrm{mg} \mathrm{cm}^{-2}$.

Single cell tests were performed in a fuel cell test fixture of $5 \mathrm{~cm}^{2}$ active area. This latter was connected to a test station from Fuel Cell Tech, Inc. For single cell polarization experiments, aqueous methanol $(2 \mathrm{M})$ was fed to the anode chamber of the DMFC through a peristaltic pump; dry oxygen was fed to the cathode. Atmospheric pressure in the anode and cathode compartments was used in the experiments. Reactant flow rates were 3 and $100 \mathrm{~cm}^{3} \mathrm{~min}^{-1}$ for the methanol/water mixture and oxygen stream, respectively. Cathode operation conditions were selected to avoid limiting effects on the cell behavior, such as methanol crossover [33], membrane dehydration, which may influence the evaluation of the anode polarizationô. In this regard, a good hydration of the membrane inside the cell was achieved by the use of oxygen feed, high pressure and high oxidant flow rates. Obviously, these conditions are not consistent with a practically viable device $[34,35]$. Single cell performances were investigated by steady-state galvanostatic polarization measurements at $30^{\circ} \mathrm{C}$ and $60^{\circ} \mathrm{C}$. Electrochemical impedance spectroscopy (EIS) data were recorded in the potentiostatic mode by using an AUTOLAB Potentiostat/Galvanostat (Metrohm), equipped with a Frecuency Response Analyses (FRA) module, applying a sinusoidal signal with an amplitude of $10 \mathrm{mV}$ and a frequency in the $10 \mathrm{KHz}-0.01 \mathrm{~Hz}$ range. The series resistance (Rs) was determined from the high frequency intercept on the real axis in the Nyquist plot. The charge transfer resistance (Rct) was taken as the difference between the extrapolated low frequency intercept and the high frequency intercept on the real axis.

Besides gas diffusion electrodes for half-cell tests were prepared according to a procedure described elsewhere [36], consisting of carbon cloth backing, gas diffusion layer and the catalytic layer under study. To reduce the flooding effects in the sulfuric 
Submitted, accepted and published in Applied Catalysis B: Environmental 147 (2014) 947-957. Post-print of:

177 acid half-cell, a hydrophobic backing layer was used (LT 1200W ELAT, E-TEK). The 178 catalytic layer was composed of $33 \mathrm{wt} . \%$ Nafion ${ }^{\circledR}$ ionomer and $67 \mathrm{wt} . \%$ catalyst, with a 179 Pt loading of $c a .0 .10 \mathrm{mg} \mathrm{cm}^{i} 2\left( \pm 0.02 \mathrm{mg} \mathrm{cm}^{i}\right)$. Half-cell tests were carried out in a 180 conventional thermostated three-electrode cell consisting on the gas diffusion electrode 181 to be tested (working electrode), a mercury-mercurous sulfate reference electrode $182\left(\mathrm{Hg} / \mathrm{Hg}_{2} \mathrm{SO}_{4}\right.$, sat. $)$ and a high surface coiled platinum wire as counter electrode. The 183 electrode geometric area was $0.2 \mathrm{~cm}^{2}$, and a $0.5 \mathrm{M} \mathrm{H}_{2} \mathrm{SO}_{4}$ aqueous solution was 184 employed as electrolyte. Gas (nitrogen or oxygen) was fed to the electrode backing 185 layer during the tests. A $\varepsilon$ Autolab Metrohm potentionstat/galvanostat was used to 186 perform the measurements. Among the various methods reported in literature [37], an accelerated stress test has been selected for the evaluation of the catalysts resistance to degradation. It consists on a continuous potential cycling between 0.6 and $1.2 \mathrm{~V} v s$. RHE up to a total of 1000 cycles, feeding nitrogen to the electrode. The evaluation of the decay process was carried out by in situ electrochemical tests: cyclic voltamperometry (from 0.02 to $1.2 \mathrm{~V}$ vs. RHE) in nitrogen and polarization curves in pure oxygen. 
Submitted, accepted and published in Applied Catalysis B: Environmental 147 (2014) 947-957. Post-print of:

\section{Results and discussion}

3.1. Influence of the synthesis method on the properties and electrochemical activity of the carbon xerogel-supported catalysts

Textural properties of the CXG and the synthesized catalysts were determined from $\mathrm{N}_{2}$ adsorption isotherms shown in Figure 1.

Isotherms present type IV shape, according to the IUPAC classification [38], with a hysteresis loop of type II. Isotherm shape for the carbon xerogel is already clearly indicative of a mesoporous carbon material, with average pore sizes extending to the wide mesopore range. Textural properties derived from these isotherms are shown in Table 1.

The carbon xerogel presents a high surface area of $528 \mathrm{~m}^{2} / \mathrm{g}$, high pore volume, $1.79 \mathrm{~cm}^{3} / \mathrm{g}$ - with more than $80 \%$ of this volume corresponding to mesopores - as well as a mean pore size around $23 \mathrm{~nm}$. The pore size distribution, shown in Figure $1 \mathrm{~b}$, points indeed to wide mesopores prevailing in the pore structure of this carbon material.

Generally, upon Pt loading, surface area and pore volume of CXG decrease. Pore blockage is already noticeable for the catalysts prepared through both impregnation routes, and becomes slightly more remarkable in the case of Pt/CXG-i-FAM. In fact, average pore sizes remain almost unaffected. On the other hand, pore volume and surface area decrease is dramatic in the case of the catalyst prepared through the microemulsion method, Pt/CXG-ME. In this last case, micropore volume is totally blocked upon active phase loading. This can be due to the presence of some rests of the surfactant employed within the synthesis of this catalyst, which remain bonded to the carbon surface, as evidenced in TGA oxidation of this catalyst (not shown). The presence of this material, even upon extensive washing, still blocks part of the porous structure of the support. Nevertheless, the catalyst preserves an important fraction of its mesoporous structure, with an average pore size of $17.1 \mathrm{~nm}$.

Figure 2 presents the XRD patterns obtained for the three carbon xerogel-based Pt-catalysts. The patterns show the typical [111], [200] and [220] diffraction peaks of Pt face centered cubic structure. Additionally, a wide and slight peak corresponding to carbon [002] diffraction can be observed and ascribed to a certain degree of graphitic ordering within the primary particles of the carbon xerogel structure. Pt crystal sizes 
Submitted, accepted and published in Applied Catalysis B: Environmental 147 (2014) 947-957. Post-print of:

were calculated from the [220] peaks, applying Scherrerô equation. The values obtained are shown in Table 2. Crystal sizes are relatively similar for the three catalysts, independently of the synthesis route followed, ranging from 3.6 to $4.2 \mathrm{~nm}$. The largest Pt crystal size, $4.2 \mathrm{~nm}$, corresponds to the catalyst prepared using the impregnation route and reduction with sodium borohydride, Pt/CXG-i-SBM, the lower, $3.6 \mathrm{~nm}$, was obtained for the catalyst prepared using formic acid as reducing agent, Pt/CXG-i-FAM. The crystal size obtained for the catalyst Pt/CXG-ME was unexpectedly high, given that this method usually provides lower crystal sizes, as previously studied in [39]. It is believed that the excessive growth of the crystal size is due to the agglomeration of the metallic precursor micelles on the surface of the carbon material.

X-ray photoelectron spectroscopy (XPS) was used in order to identify the chemical state of the Pt species on the surface of the different catalysts prepared. $\mathrm{Pt}$ 4f core level region was curve fitted to three sets of spin-orbital doublets, namely accounting for $4 \mathrm{f}_{7 / 2}$ and $4 \mathrm{f}_{5 / 2}$ peaks. Contributions at 71.4, 72.7 and $75.1 \mathrm{eV}$, and 74.8, 76.1 and $78.4 \mathrm{eV}$, were assigned to $\mathrm{Pt}^{0}, \mathrm{Pt}^{2+}(\mathrm{PtO})$ and $\mathrm{Pt}^{4+}\left(\mathrm{PtO}_{2}\right)$ oxidation states, respectively, based on the existing literature on XPS studies of carbon-based Pt catalysts [40-41]

Table 3 contains the percentages of each species after quantitative deconvolution of the peaks, shown in Figure 3. Generally, $\mathrm{Pt}^{0}$ was found to be the predominant species on the surface of this series of catalysts. There is, however, an important contribution of oxidized $\mathrm{Pt}^{2+}$, as well as of $\mathrm{Pt}^{4+}$. XPS analysis evidences similar contents in reduced $\mathrm{Pt}$, $\mathrm{Pt}^{0}$, for the catalysts prepared by impregnation methods, being slightly higher in the case of the catalyst prepared using formic acid as reductant, Pt/CXG-i-FAM. In spite of the stronger reduction character of sodium borohydride in comparison to formic acid, the low temperature employed in the synthesis of the catalyst prepared using sodium borohydride may be responsible for the lower amount of reduced Pt in Pt/CXG-i-SBM, as well as in the catalyst prepared through the microemulsion route, which shows the lowest content in $\mathrm{Pt}^{0}$. Reduction is particularly hindered in this last case due to the fact that the reducing agent has to go through the micelle before reaching the core containing the Pt precursor.

Figure 4 shows the TEM images acquired for the three different catalysts, as well as their corresponding histograms. Different extents of metal dispersion can be observed, as well as different particle sizes and morphologies. In principle, the catalyst 
Submitted, accepted and published in Applied Catalysis B: Environmental 147 (2014) 947-957. Post-print of:

showing a more adequate Pt-dispersion is the one prepared following the formic acid route, Pt/CXG-i-FAM, Figure 4b. The corresponding histogram evidences mean particle size value slightly lower than the one predicted by means of XRD, around $2.7 \mathrm{~nm}$, but in any case it remains the lowest of the series of catalysts. Synthesis by means of the borohydride route, Pt/CXG-i-SBM, Figure 4a, results in an almost bi-modal particle size distribution. The corresponding histogram shows 2 peaks, one centered in sizes about $3.2 \mathrm{~nm}$, the other at about $4.5 \mathrm{~nm}$, pointing to the presence of both isolated particles of lower size together with some others which tend to agglomerate to a higher extent. Morphology of Pt-particles in the catalyst prepared by means of the microemulsion method, Figure 4c, looks completely different to those observed in the impregnated catalysts. Though particles appear to be individually slightly smaller than in the other cases, they tend to agglomerate forming chain-like structures, with an average size centered at $4.3 \mathrm{~nm}$. The dispersion of the active phase seems to be worst for this microemulsion catalyst, Pt/CXG-ME. It is believed that the micelles of surfactant and precursor are too big to enter the pores of the carbon material, in agreement with higher extent of pore blockage evidenced in the textural characterization of this catalyst (Table 1). Micelles then get agglomerated on the carbon surface, as a consequence of the interaction of consecutive nearby micelles.

Regarding the electrochemical characterization and activity of this series of catalysts, Figure $5 \mathrm{a}$ and $5 \mathrm{~b}$ shows the polarization and power curves at $30^{\circ} \mathrm{C}$ and $60^{\circ} \mathrm{C}$ respectively, for the DMFC equipped with the various Pt/CXG catalysts at the cathode. Among the three CXG-supported catalysts, the one prepared following the formic acid route, $\mathrm{Pt} / \mathrm{CXG}-\mathrm{i}-\mathrm{FAM}$, evidences the best performance at both temperatures $\left(30^{\circ} \mathrm{C}\right.$ and $60^{\circ} \mathrm{C}$ ), with maximum values of power density of 12 and $38 \mathrm{~A} \cdot \mathrm{g}^{-1} \mathrm{Pt}$ (equivalent to 12 and $38 \mathrm{~mW} \cdot \mathrm{cm}^{-2}$, given that the total loading of the MEA was $1 \mathrm{mg} \cdot \mathrm{cm}^{-2}$ ). Differences between Pt/CXG-i-FAM and the other two catalysts, become more pronounced when operating the cell at $60{ }^{\circ} \mathrm{C}$. Catalysts prepared through the borohydride and microemulsion methods show very similar behavior, particularly in the high density region, given their similar physico-chemical properties, such as less uniform metallic dispersion (in comparison to Pt/CXG-i-FAM) and higher crystal size (4,2 and 3,9 nm, respectively). Figure $5 \mathrm{c}$ shows a zoom of the polarization curve in the activation zone at $30^{\circ} \mathrm{C}$. As can be seen, the catalyst Pt/CXG-i-FAM, presents the highest intrinsic activity, given its more appropriate crystal size, $3.6 \mathrm{~nm}$, closer to the optimum size of 3 
Submitted, accepted and published in Applied Catalysis B: Environmental 147 (2014) 947-957. Post-print of:

$\mathrm{nm}$ for the ORR determined by Kinoshita et al. [42]. The catalyst Pt/CXG-i-SBM, although presenting the highest crystal size, shows a slightly higher intrinsic activity in the activation region of the curve, in comparison to the Pt/CXG-ME catalyst, probably due to its better metallic dispersion.

Current density in polarization curves was also represented as $\mathrm{mA} \cdot \mathrm{cm}^{-2}$ and power density in terms of $\mathrm{mW} \cdot \mathrm{cm}^{-2}$, in order to compare the results with the ones available in literature [43], as presented in Figure $6 \mathrm{a}$ and $6 \mathrm{~b}$ (measured at $30^{\circ} \mathrm{C}$ and $60^{\circ} \mathrm{C}$, respectively). As the electrodes were prepared with $1 \mathrm{mg} \cdot \mathrm{cm}^{-2}$ of $\mathrm{Pt}$, polarization curves show the same order of magnitude as expressed by $\mathrm{mA}$ or $\mathrm{mW}$ per $\mathrm{g}$ of $\mathrm{Pt}$.

Brouzgou et al. [43] presented a review of low and non-platinum electrocatalysts for PEMFCs, including DMFCs. According to their review, catalysts are classified in three regions: (i) catalysts with maximum mass specific power density higher than 0.1 $\mathrm{mW} \cdot \mathrm{g}^{-1} \mathrm{Pt}_{\text {total }}$, (ii) catalysts with maximum mass specific power density between 0.01 $\mathrm{mW} \cdot \mathrm{g}^{-1} \mathrm{Pt}_{\text {total }}$, and $0.1 \mathrm{~mW} \cdot \mathrm{g}^{-1} \mathrm{Pt}_{\text {total }}$, and (iii) catalysts with maximum mass specific power density lower than $0.01 \mathrm{~mW} \cdot \mathrm{g}^{-1} \mathrm{Pt}_{\text {total. }}$. The catalysts presented in this work are found in the low part of the second region, with maximum mass specific power density between $0.01 \mathrm{~mW} \cdot \mathrm{g}^{-1} \mathrm{Pt}_{\text {total }}$, and $0.1 \mathrm{~mW} \cdot \mathrm{g}^{-1} \mathrm{Pt}_{\text {total }}$, with performances similar to those reported by Antolini et al. [44]. One must take into consideration the low temperature used in the present work.

Electrochemical impedance spectroscopy was studied at $0.2 \mathrm{~V}, 30^{\circ} \mathrm{C}$ and $60^{\circ} \mathrm{C}$ in the same conditions than polarization curves. The Nyquist plots are represented in Figure $7 \mathrm{a}$ and $7 \mathrm{~b}$. The lowest Rct was observed both at $30{ }^{\circ} \mathrm{C}$ and $60{ }^{\circ} \mathrm{C}$ for the catalyst prepared by means of the formic acid route, Pt/CXG-i-FAM, as a proof of its higher intrinsic activity, proved previously by the polarization curves. The highest Rct was observed for the catalyst prepared by impregnation and reduction with sodium borohydride, Pt/CXG-i-SBM method, in line with the results obtained at that potential in the polarization curves. The Rs is similar for all the MEAs; its value is around 0.5 $\mathrm{ohm} \cdot \mathrm{cm}^{2}$, which is slightly larger than for conventional cells based on catalysts supported on commercial carbon black [45]. The low electrical conductivity of these carbon materials may be responsible for this slight increase in Rs, compared to other studies [46]. Once again, differences encountered between Pt/CXG-i-FAM and the other two catalysts, are more significative at $60{ }^{\circ} \mathrm{C}$. 
Submitted, accepted and published in Applied Catalysis B: Environmental 147 (2014) 947-957. Post-print of:

\subsection{Comparison with Pt supported on commercially available carbon support, Vulcan- $X C-72-R$.}

After determining the most favorable synthesis method, a comparison with a commercially available carbon support, Vulcan-XC-72R, was carried out. Pt particles were deposited on Vulcan by impregnation and reduction with formic acid, in the same conditions previously established for Pt/CXGs catalysts.

Both BET surface area and pore volume of the carbon xerogel (see Table 1) double those of Vulcan carbon black. Moreover, though well known for being a mesoporous material, with a low content in micropores, Vulcan carbon black shows an average pore size of $11 \mathrm{~nm}$, as observed in Figure 8b, that is, its pores are in average more than two times narrower than those in the carbon xerogel. Table 4 shows the textural parameters determined by means of $\mathrm{N}_{2}$ adsorption isotherms (shown in Figure 8a), for both the carbon black, Vulcan, and the catalyst prepared using Vulcan as support.

As previously observed for the carbon xerogel-supported catalysts, surface area and mesopore volume decrease as well for Vulcan carbon black, upon the incorporation of the active phase. Although pore volume decreases only a $24 \%$ as a consequence of pore blockage in the Vulcan-supported catalyst, and this decrease is almost double, $42 \%$ in the case of the carbon xerogel-supported one, the latter still shows much higher surface area and pore volume than the former, preserving as well the average pore size, as a consequence of the initially highly developed porous structure of this material.

XRD pattern, acquired for the Vulcan supported catalyst, along with a TEM image of this catalyst, are both shown in Figure 9. As can be observed, good dispersion of the active phase can be as well achieved when using Vulcan carbon black as support. In spite of its less developed porous structure, Pt particles appear adequately distributed. The different morphology of this material can be also observed in this image, its structure mostly composed by spherical primary particles which internally present a certain degree of graphitic short-range order. This sort of ordered structure results, in fact, in an enhanced ability of this carbon material to disperse the electronic charge of the loaded metal, which may explain the good distribution of Pt particles achieved in spite of other structural drawbacks, in comparison to the synthesized carbon xerogel. 
Submitted, accepted and published in Applied Catalysis B: Environmental 147 (2014) 947-957. Post-print of:

Pt crystal size was calculated from the [220] peaks, applying Scherrerô equation, as shown in Table 5. Catalyst prepared using Vulcan carbon black as support shows a Pt crystal size of $3.4 \mathrm{~nm}$, slightly lower than the one calculated for the catalyst prepared using the carbon xerogel. XPS analysis for both catalysts, also shown in Table 5, evidences a slightly lower content in reduced Pt for the catalyst supported on the commercial support, Pt/Vulcan, in comparison to the Pt/CXG catalyst.

Differences of carbon structure are shown in Figure 10, in the XPS spectra of carbon materials. $\mathrm{C} 1 \mathrm{~s}$ band was deconvoluted into five components [40]. The contribution at 284.5-284.6 eV can be ascribed to the presence of C-C bonds in graphitic carbon. A peak at ca. $284.9-285.3 \mathrm{eV}$ is related to the presence of defects in the graphitic structure of the carbon material. Whereas, peaks at ca. $286.7 \mathrm{eV}$ and 287.8 $\mathrm{eV}$ account for the presence of oxidized carbon, in the form of $\mathrm{C}-\mathrm{O}$ and $\mathrm{C}=\mathrm{O}$ species, respectively. Finally, a low intensity and broad band at ca. $290 \mathrm{eV}$ is traditionally attributed to ' $-' *$ transition characteristic of pure graphitic samples, sometimes considered as an indirect measure of the graphitic character of carbon blacks.C-C peak centred at $284.6 \mathrm{eV}$ is predominant in the $\mathrm{C} 1 \mathrm{~s}$ band, as a consequence of a high degree of cross-linking in the organic gel, leading to a carbon material which possesses a certain degree of short range order, as previously described in [47]. However, this C-C peak is accompanied by a significant contribution corresponding to functionalized $\mathrm{C}$; $\mathrm{C}$ $\mathrm{O}$ and $\mathrm{C}=\mathrm{O}$ peaks. Such contributions appear less intense in the case of the commercial carbon black Vulcan, pointing to poor surface chemistry for this material, almost lacking of oxygen heteroatoms.

With respect to the electrochemical behavior of the carbon black-supported catalyst, in comparison to the carbon xerogel-based one, Figure 11 shows the polarization and power curves at $30^{\circ} \mathrm{C}$ and $60{ }^{\circ} \mathrm{C}$ for the DMFC equipped with the Pt/CXG-i-FAM and Pt/CB-Vulcan-i-FAM catalysts at the cathode. The catalyst supported on CXG, prepared following the formic acid route, Pt/CXG-i-FAM, evidences higher performance than the catalyst supported on the commercial support, $\mathrm{Pt} / \mathrm{CB}-\mathrm{Vulcan}-\mathrm{i}-\mathrm{FAM}$, prepared by using the same method at $30^{\circ} \mathrm{C}$, Figure $11 \mathrm{a}$. At 60 ${ }^{\circ} \mathrm{C}$, Figure $11 \mathrm{~b}$, both catalysts shows very similar performances, being slightly higher for the Pt/CB-Vulcan-i-FAM, given the more graphitic character of the carbon material, making it slightly more resistant to the more stringent conditions of the cell at $60^{\circ} \mathrm{C}$. 
Submitted, accepted and published in Applied Catalysis B: Environmental 147 (2014) 947-957. Post-print of:

Electrochemical impedance spectroscopy was studied at $0.2 \mathrm{~V}, 30^{\circ} \mathrm{C}$ and $60{ }^{\circ} \mathrm{C}$ in the same conditions than polarization curves. The Nyquist plots are represented in Figure 12. The catalyst prepared by means of the formic acid route, Pt/CXG-i-FAM presented the lowest Rct, in comparison to Pt/Vulcan-i-FAM. On the contrary, the lowest series resistance was observed for the catalyst prepared with the commercial support, Pt Pt/Vulcan-i-FAM given its highly conductive character, as previously described in $[31,46]$ resulting in lower ohmic resistance.

Further analyses in a half-cell system provided with a gas diffusion electrode (GDE) in a $0,5 \mathrm{M} \mathrm{H}_{2} \mathrm{SO}_{4}$ solution at room temperature, were carried out, in order to determine the mechanism of the ORR by means of the Tafel plot. Figure 13a shows polarization curves in terms of specific activity, that was calculated dividing mass activity by the electrochemically active surface area (ECSA, $\mathrm{m}^{2} / \mathrm{g} \mathrm{Pt}$ ) determined from the integration of the area under the peak of the $\mathrm{H}$ adsorption during cyclic voltammetry.

Figure 13a clearly shows how the carbon xerogel-supported catalyst presents higher specific activity than the carbon-black supported catalyst. Besides, accelerated degradation tests (ADT) were carried out in order to determine the stability of both catalysts. The inset in Figure 13a shows the specific activity at $0.8 \mathrm{~V}$ vs RHE of both catalysts before and after the ADT. As clearly seen, Pt/CB-Vulcan-i-FAM shows higher resistance to corrosion than the Pt/CXG-i-FAM. The specific activity of the Pt/CBVulcan-i-FAM catalyst decreases a $23 \%$ after ADT, whereas for the Pt/CXG-i-FAM, the specific activity decreases a $45 \%$. One must take into account that the surface area of the carbon xerogel doubles the one of Vulcan, and so is more prone to corrosion. However, the carbon xerogel supported catalyst shows higher specific activity after the degradation test in comparison to Pt/CB-Vulcan-i-FAM. Figure 13b shows Tafel plots for both catalysts, that present very similar performances in the activation controlled region, but slightly higher for the carbon xerogel supported catalyst. Tafel slopes are very similar, $67 \mathrm{mV} \cdot \mathrm{dec}^{-1}$ for the $\mathrm{Pt} / \mathrm{CB}-$ Vulcan-i-FAM and $71 \mathrm{mV} \cdot \mathrm{dec}^{-1}$ for the Pt/CXG-i-FAM, indicating a Temkin-type mechanism for the ORR of 4 electrons. on electrical conductivity and graphitic structure, in comparison to the commercial support. This leads to higher ohmic losses and higher corrosion when using carbon xerogels as supports, but also to the possibility of using high metal loadings. Further 
Submitted, accepted and published in Applied Catalysis B: Environmental 147 (2014) 947-957. Post-print of:

423 studies will concern not only on increasing metal loading, but also on the improvement 424 of the structural features of the carbon xerogel in order to miminize the ohmic losses 425 and corrosion. Higher carbonization temperatures will be used during the pyrolysis step 426 in order to increase the short range order of this carbon material. Besides the 427 introduction of dopants such as nitrogen, boron [48, 49] or $\mathrm{WO}_{3}$ [50], previously 428 reported in literature as effective ways of improving carbon $\hat{Q}$ electrical conductivity $429[50,51]$, will be taken in consideration. 
Submitted, accepted and published in Applied Catalysis B: Environmental 147 (2014) 947-957. Post-print of:

\section{Conclusions}

A highly mesoporous carbon xerogel was used as the carbon support in the preparation of Pt-catalysts, following several synthesis routes: two impregnation methods using both sodium borohydride (SBM) and formic acid (FAM) as reducing agents, and a microemulsion method.

Different synthesis routes led to catalysts having different physico-chemical properties. The catalyst prepared through the formic acid impregnation method showed the lowest crystal size and slightly higher amount of reduced Pt on its surface. TEM analysis pointed to a better dispersion of the metallic particles in this case. The FAM catalysts presented the highest electrocatalytic activity. Both polarization and power density curves together with the impedance study evidenced enhanced performance for this catalyst over the rest of the catalysts of this series.

When compared to an analogously prepared Vulcan carbon black-supported catalyst, the xerogel based-catalyst still showed enhanced activity. The advanced textural properties of the xerogel carbon support allow the conservation of an important amount of wide mesopores (around $23 \mathrm{~nm}$ ), even upon active phase loading. Not so many differences were observed between the two catalysts in terms of Pt crystal size. Moreover, Pt dispersion looks adequate in the Vulcan-supported catalysts. XPS pointed, however, to an enhanced presence of Pt reduced species on the surface of the carbon xerogel-based catalyst. Though polarization and power density curves evidenced a better performance of the carbon xerogel-based catalyst, impedance studies showed that ohmic losses are more important when using this material as support, than when using the commercially available carbon black. This can be due to the higher electrical conductivity of Vulcan, in comparison to the carbon xerogel. However, the good results obtained point to this synthetic carbon material, carbon xerogel, as a highly promising electrocatalyst support. Its enhanced textural features make it possible to load higher amounts of Pt than the one used in the present work. There is still plenty of room for improvement, in terms of i.e. increasing the electrical conductivity of the materials, which would lead to a promising material for such applications. 
Submitted, accepted and published in Applied Catalysis B: Environmental 147 (2014) 947-957. Post-print of:

\section{Acknowledgements}

The authors want to thank the financial support of the bilateral CNR (Italy) $\ddot{i}$ CSIC (Spain) joint agreement 2011-2012 (project Baglio/Lazaro 2010IT0026). M.E. Gálvez is indebted to the Spanish Ministry of Economy and Competitiveness (Secretaría de Estado de I+D+i) for her ñRamón y Cajalò contract. CNR-ITAE authors acknowledge the financial support of PRIN 2010-11 project "Advanced nanocomposite membranes and innovative electrocatalysts for durable polymer electrolyte membrane fuel cells (NAMED-PEM)ò.

\section{References}

[1] I. Gatto, A. Stassi, E. Passalacqua, A.S. Aricò. Int. J. Hydrogen Energy 38 (2013) $675-681$.

[2] H.A. Gasteiger, S.S. Kocha, B. Sompalli, F.T. Wagner. Appl. Catalysis B: Environmental 56 (2005) 9ï 35

[3] R.S. Amin, R.M. Abdel Hameed, K.M. El-Khatib, H. El-Abda, E.R. Souay. Int. J. Hydrogen Energy 37 (2012) 18870ї 18881.

[4] A.S. Aricò, V. Baglio, V. Antonucci. Electrocatalysis of Direct Methanol Fuel Cells. Edited by Hansan Liu and Jiujun Zhang; Direct Methanol Fuel Cells: History, Status and Perspectives. 2009 WILEY-VCH Verlag GmbH \& Co. KGaA, Weinheim. ISBN: 978-3-527ї 32377-7.

[5] A.H.A. Monteverde Videla, L. Zhang, J. Kim, J. Zeng, C. Francia, J. Zhang, S. Specchia. J. Appl. Electrochem. 43 (2013) 159-169.

[6] A. Chen, P. Holt-Hindle. Chem. Rev. 110 (2010) $3767 і ̈ 3804$.

[7] M. Lefèvre, E. Proietti, F. Jaouen, J.P. Dodelet. Science 324 (2009) 71-74.

[8] C.H. Choi, S.Y. Lee, S.H. Park, S.I. Woo. Appl. Catalysis B: Environmental 103 (2011) $362 і ̈ 368$.

[9] B. Merzougui, A. Hachimi, A. Akinpelu, S. Bukola, M. Shao. Electrochimica Acta 107 (2013) 126-132.

[10] M. Rahsepar, M. Pakshir, H. Kim. Electrochimica Acta 2013; http://dx.doi.org/10.1016/j.electacta.2013.07.028. 
Submitted, accepted and published in Applied Catalysis B: Environmental 147 (2014) 947-957. Post-print of:

[11] A. Bauer, R. Hui, A. Ignaszak, J. Zhang, D. Jones. J. Power Sources 210 (2012) 1520 .

[12] A. Brouzgou, S.Q. Song, P. Tsiakaras. Appl. Catalysis B: Environmental 127 (2012) $371 і ̈ 388$.

[13] E. Antolini. Appl. Catalysis B: Environmental 88 (2009) 1 1ї 24.

[14] J. Zeng, C. Francia, M.A. Dumitrescu, A.H.A. Monteverde Videla, V.S. Ijeri, S. Specchia, P. Spinelli. Industrial and Engineering Chemistry Research 51 (22) (2012) 7500-7509.

[15] C. Wang, N.M. Markovic, V.R. Stamenkovic. ACS Catalysis 2 (2012) 891̄ 898.

[16] D.A. Cantane, F.E.R. Oliveira, S.F. Santos, F.H.B. Lima. Appl. Catalysis B: Environmental 136ї 137 (2013) 351ї 360.

[17] G. Zhang, Z.G. Shao, W. Lu, F. Xie, H. Xiao, X. Qin, B. Yi. Appl. Catalysis B: Environmental 132ï 133 (2013) 183ї 194.

[18] A. Stassi, I. Gatto, V. Baglio, E. Passalacqua, A.S. Aricò. J. Power Sources 222 (2013) 390-399.

[19] A.S. Aricò, V. Baglio, A. Di Blasi, E. Modica, P.L. Antonucci, V. Antonucci. Journal of Electroanalytical Chemistry 557 (2003) 167-176.

[20] M Götz, H Wendt. Electrochimica Acta 43 (1998) 3637-3644.

[21] H. Bönnemann, G. Braun, W. Brijoux, R. Brinkmann, A. Schulze Tilling, K. Seevogel, K. Siepen. Journal of Organometallic Chemistry 520 (1996) 143-162.

[22] A.S. Aricò, V. Baglio, A. Di Blasi, E. Modica, G. Monforte, V. Antonucci. Journal of Electroanalytical Chemistry 576 (2005) 161-169.

[23] N. Job, R. Pirard, J. Marien, J.P. Pirard. Carbon 42 (2004) $3217 і ̈ 3227$.

[24] C. Arbizzani, S. Righi, F. Soavi, M. Mastragostino. Int. J. Hydrogen Energy 36 (2011) 5038-5046.

[25] S.A. Al-Muhtaseb, J.A. Ritter. Adv. Mater. 15 (2003) $101 \ddot{1} 114$.

[26] N. Job, M.F.R. Pereira, S. Lambert, A. Cabiac, G. Delahay, J.F. Colomer, J. Marien, J.L. Figueiredo, J.P. Pirard. J. Catalysis 240 (2006) 160ї 171. 
Submitted, accepted and published in Applied Catalysis B: Environmental 147 (2014) 947-957. Post-print of:

[27] P.V. Samant, J.B. Fernandes, C.M. Rangel, J.L. Figueiredo. Catalysis Today 102ï 103 (2005) $173 \ddot{\mathrm{I}} 176$.

[28] N. Job, J. Marie, S. Lambert, S. Berthon-Fabry, P. Achard. Energy Conversion and Management 49 (2008) 2461ї 2470.

[29] C. Arbizzani, S. Beninati, E. Manferrari, F. Soavi, M. Mastragostino. J. Power Sources 172 (2007) 578-586.

[30] S. Lambert, N. Job, L. D'Souza, M.F.R. Pereira, R. Pirard, B. Heinrichs, J.L. Figueiredo, J.P. Pirard, J.R. Regalbuto. J. Catalysis 261 (2009) 23 Ï 33.

[31] D. Sebastián, C. Alegre, L. Calvillo, M. Pérez, R. Moliner, M.J. Lázaro. Int. J. Hydrogen Energy, http://dx.doi.org/10.1016/j.ijhydene.2013.04.016

[32] Sebastián, D., Lázaro, M.J., Suelves, I., Moliner, R., Baglio, V., Stassi, A., Aricò, A.S. Int. J. Hydrogen Energy 37 (2012) 6253-6260.

[33] Y.Z. Fu, A. Manthiram. J. Power Sources 157 (2006) 222ï 225.

[34] A.S. Aricò, P.L. Antonucci, E. Modica, V. Baglio, H. Kim, V. Antonucci. Electrochim. Acta 47 (2002) 3723-3732.

[35] A.S Aricò, P CretēsE Modica, G Monforte, V Baglio, V Antonucci. Electrochim. Acta 45 (2000) 4319ї 4328

[36] Baglio V., Di Blasi A., Aricò A.S., Antonucci V., Antonucci P.L., Nannetti F., Tricoli V. Electrochim. Acta 50 (2005) 5181 ï 5188.

[37] Borup, R.; Meyers, J.; Pivovar, B.; Kim, Y.S.; Mukundan, R.; Garland, N.; Meyers, D.; Wilson, M.; Garzon, F.; Wood, D.; et al. Chem. Rev. 107 (2007) 3904 ï 3951.

[38] K.S.W. Sing, D.H. Everett, R.A.W. Haul, L. Moscou, R.A. Pierotti, J. Rouquerol, T. Siemieniewska. Pure Appl. Chem. 57 (1985) 603ð 619.

[39] D. Sebastián, I. Suelves, R. Moliner, M.J. Lázaro, A. Stassi, V. Baglio, A. S. Aricò. Appl. Catalysis B: Environmental 132ї 133 (2013) $22 і ̈ 27$.

[40] A. Velázquez-Palenzuela; F. Centellas, J.A. Garrido, C. Arias, R. M. Rodríguez, E. Brillas, P.L. Cabot. J. Physical Chemistry C 11 (2010) 4399-4407.

[41] R.K. Raman, A.K. Shukla, A. Gayen, M.S. Hegde, K.R. Priolkar, P.R. Sarode, S. Emura. J. Power Sources 157 (2006) 45-55. 
Submitted, accepted and published in Applied Catalysis B: Environmental 147 (2014) 947-957. Post-print of:

[42] K. Kinoshita. J. Electrochemical Society 137 (1990) 845-848.

[43] A. Brouzgou, S.Q. Song, P. Tsiakaras. Appl. Catalysis B: Environmental 127 (2012) $371 \ddot{i} 388$.

[44] E. Antolini, J.R.C. Salgado, E.R. Gonzalez. J. Electroanal. Chemistry 580 (1) (2005) 145-154

[45] J.L. Gómez de la Fuente, M.V. Martínez-Huerta, S. Rojas, P. HernándezFernández, P. Terreros, J.L.G. Fierro, M.A. Peña. Appl. Catalysis B: Environmental 88 (2009) 505-514.

[46] J. Li, X. Wang, Y. Wang, Q. Huang, C. Dai, S. Gamboa, P.J. Sebastian. J. NonCryst. Solids 354 (2008) 19 ï 24

[47] C. Alegre, M.E. Gálvez, R. Moliner, V. Baglio, A. Stassi, A.S. Aricò, M.J. Lázaro. ChemCatChem, 2013, DOI: 10.1002/cctc.201300542

[48] J.P. Paraknowitsch, A. Thomas, M. Antonietti. J. Mater. Chem. 20 (2010) 6746ï 6758

[49] H. Mousavi, R. Moradian. Solid State Sciences 13 (2011) 1459ï 1464.

[50] R. Ismagilov, A.E. Shalagina, O. Yu. P. Arkady, V. Ischenko, L.S Kibis, A.I. Boronin, Y.A. Chesalov, D.I. Kochubey, A.I. Romanenko, O.B. Anikeeva, T.I. Buryakov, E.N. Tkachev. Carbon 47 (2009) 1922-1929.

[51] J. Zeng, C. Francia, C. Gerbaldi, V. Baglio, S. Specchia, A.S. Aricò, P. Spinelli. Electrochim. Acta 94 (2013) 80 ï 91. 
Submitted, accepted and published in Applied Catalysis B: Environmental 147 (2014) 947-957. Post-print of:

\section{Figure captions.}

Figure 1. (a) $\mathrm{N}_{2}$ isotherms at $77 \mathrm{~K}$ and (b) Pore size distributions, obtained for both carbon xerogel and Pt-catalysts.

Figure 2. XRD patterns for the Pt-catalysts.

Figure 3. XPS spectra for the catalyst Pt/CXG-ME.

Figure 4. TEM images and histograms for a) Pt/CXG-i-SBM, b) Pt/CXG-i-FAM and c) $\mathrm{Pt} / \mathrm{CXG}-\mathrm{ME}$.

Figure 5. (a) Polarization (empty symbols) and power density (filled symbols) curves expressed in terms of $\mathrm{A} \cdot \mathrm{g}^{-1} \mathrm{Pt}$, in direct methanol single cell at $30^{\circ} \mathrm{C}$. (b) Polarization (empty symbols) and power density (filled symbols) curves in direct methanol single cell at $60^{\circ} \mathrm{C}$ (c) Zoom of the low current-density area from the polarization curves in direct methanol single cell at $30{ }^{\circ} \mathrm{C}$. Conditions: $2 \mathrm{M} \mathrm{CH}_{3} \mathrm{OH}$. Pure oxygen; Pt loading at both anode and cathode $0.5 \mathrm{mg} \cdot \mathrm{cm}^{-2}$

Figure 6. (a) Polarization (empty symbols) and power density (filled symbols) curves expressed in terms of $\mathrm{mA} \cdot \mathrm{cm}^{-2}$, in direct methanol single cell at $30^{\circ} \mathrm{C}$. (b) Polarization (empty symbols) and power density (filled symbols) curves in direct methanol single cell at $60^{\circ} \mathrm{C}$. Conditions: $2 \mathrm{M} \mathrm{CH}_{3} \mathrm{OH}$. Pure oxygen; Pt loading at both anode and cathode $0.5 \mathrm{mg} \cdot \mathrm{cm}^{-2}$

Figure 7. Electrochemical impedance spectra obtained in single cell. $0.2 \mathrm{~V}$ at (a) $30{ }^{\circ} \mathrm{C}$ and (b) $60^{\circ} \mathrm{C}$.

Figure 8. (a) $\mathrm{N}_{2}$ isotherms at $77 \mathrm{~K}$ and (b) Pore size distributions obtained for both commercial support, Vulcan and Pt/Vulcan-i-FAM catalyst.

Figure 9. XRD pattern for the Pt/Vulcan-i-FAM catalyst, along with a micrograph obtained by TEM, with its corresponding histogram.

Figure 10. XPS spectra for both carbon supports, CXG and Vulcan, and for Pt/C catalysts, Pt/CXG-i-FAM and Pt/Vulcan-i-FAM.

Figure 11. Polarization (empty symbols) and power density (filled symbols) curves in direct methanol single cell for both Pt-catalysts synthesized by impregnation and 
Submitted, accepted and published in Applied Catalysis B: Environmental 147 (2014) 947-957. Post-print of:

reduction with formic acid at (a) $30^{\circ} \mathrm{C}$ and (b) $60{ }^{\circ} \mathrm{C}$ in a $2 \mathrm{M} \mathrm{CH}_{3} \mathrm{OH}$ solution, feeding pure oxygen; $\mathrm{Pt}$ loading at both anode and cathode $0.5 \mathrm{mg} \cdot \mathrm{cm}^{-2}$.

Figure 12. Electrochemical impedance spectra obtained in single cell for both Ptcatalysts synthesized by impregnation and reduction with formic acid. $0.2 \mathrm{~V}$ at (a) $30^{\circ} \mathrm{C}$ and (b) $60^{\circ} \mathrm{C}$.

Figure 13. (a) Polarization curves and (b) Tafel plots performed in a gas diffusion electrode, feeding pure oxygen at room temperature in a $0,5 \mathrm{M} \mathrm{H}_{2} \mathrm{SO}_{4}$ solution. Inset shows the specific activity of both catalysts before and after accelerated degradation tests. Specific activity was calculated dividing mass activity by the electrochemically active surface area (ECSA, $\mathrm{m}^{2} / \mathrm{g} \mathrm{Pt}$ ) determined from the integration of the area under the peak of the $\mathrm{H}$ adsorption during cyclic voltammetry. 
Submitted, accepted and published in Applied Catalysis B: Environmental 147 (2014) 947-957. Post-print of:

Figure 1.

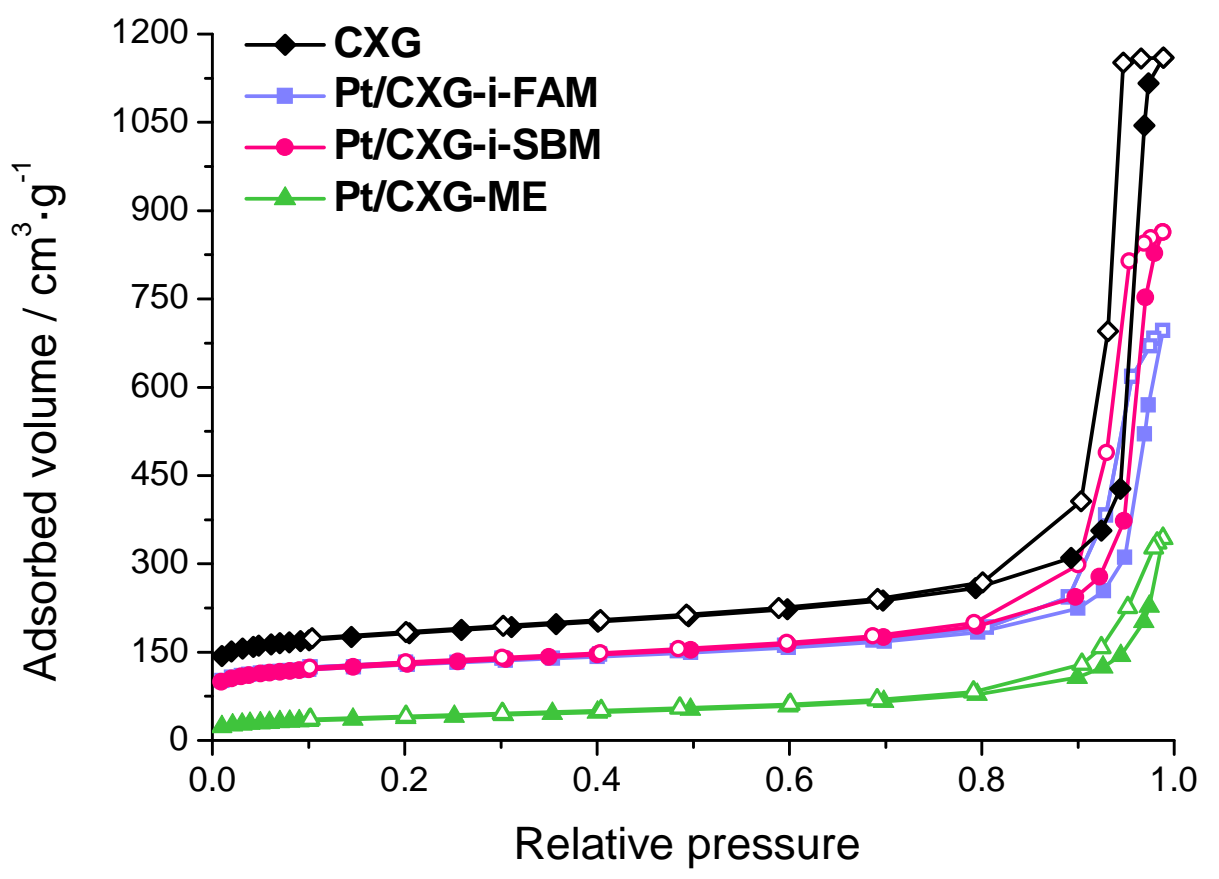

(a)

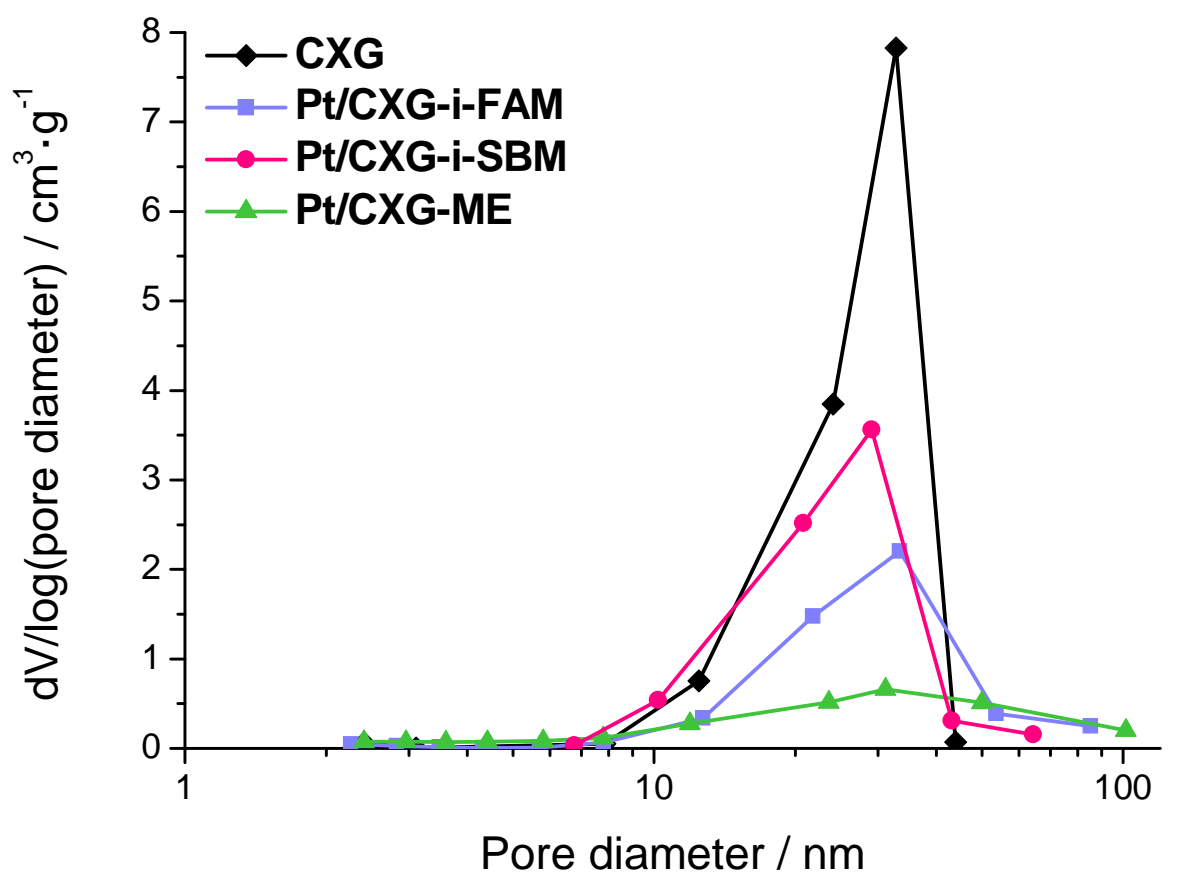

(b) 
Submitted, accepted and published in Applied Catalysis B: Environmental 147 (2014) 947-957. Post-print of:

Figure 2.

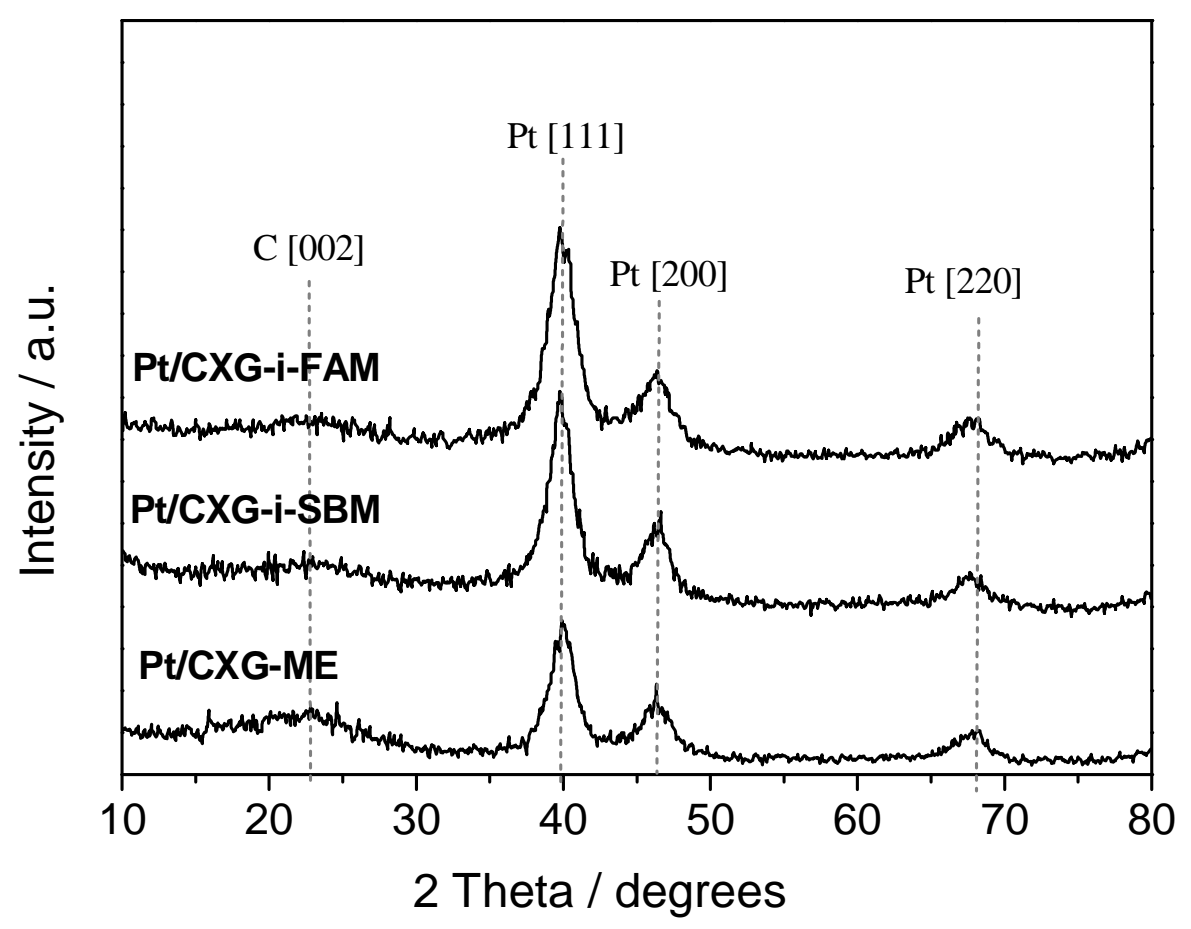


Submitted, accepted and published in Applied Catalysis B: Environmental 147 (2014) 947-957. Post-print of:

Figure 3.

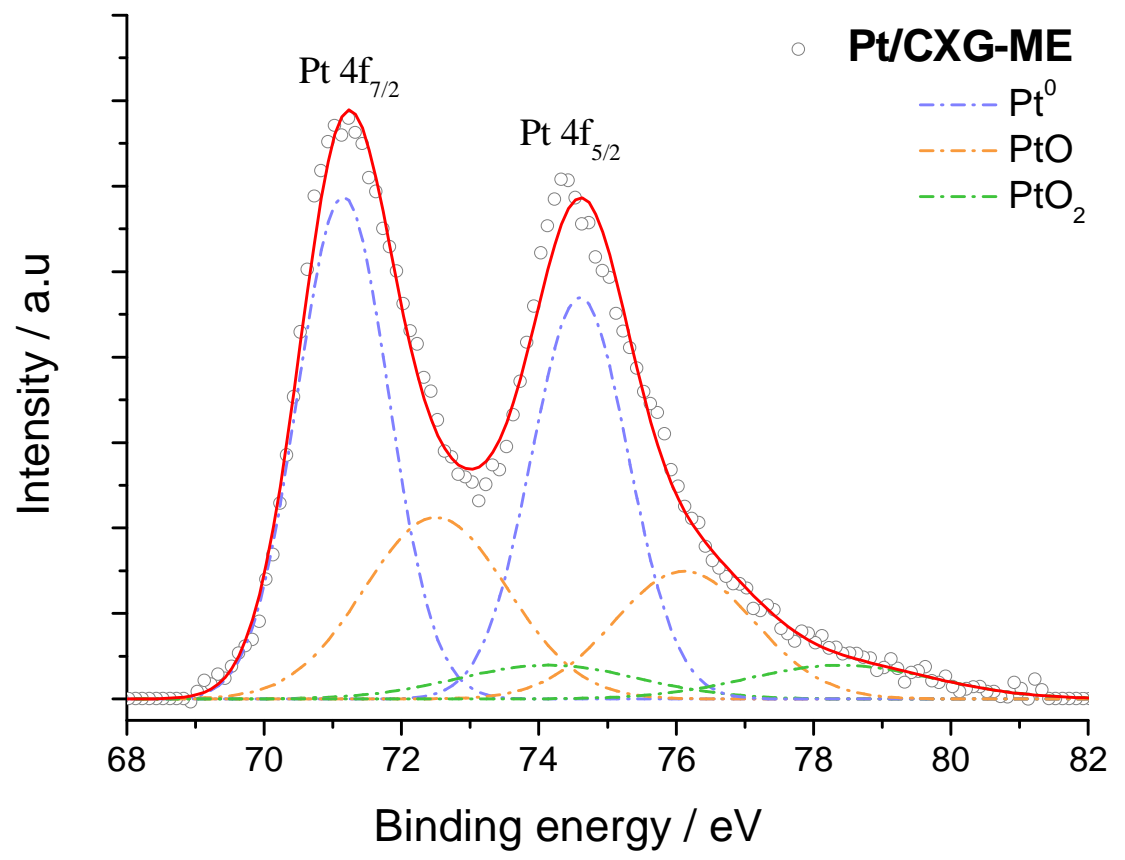


Submitted, accepted and published in Applied Catalysis B: Environmental 147 (2014) 947-957. Post-print of:

Figure 4.
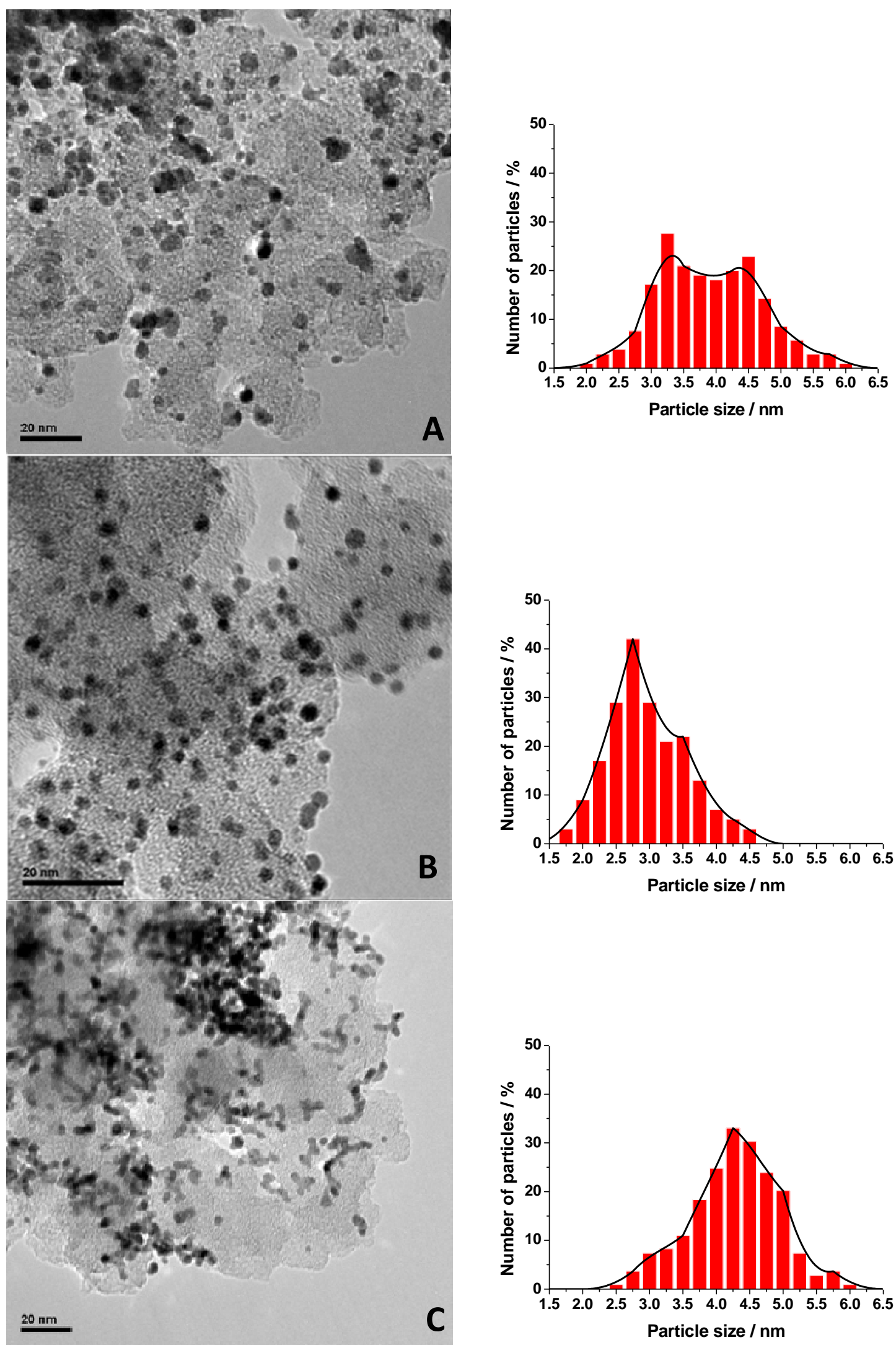
Submitted, accepted and published in Applied Catalysis B: Environmental 147 (2014) 947-957. Post-print of:

Figure 5.
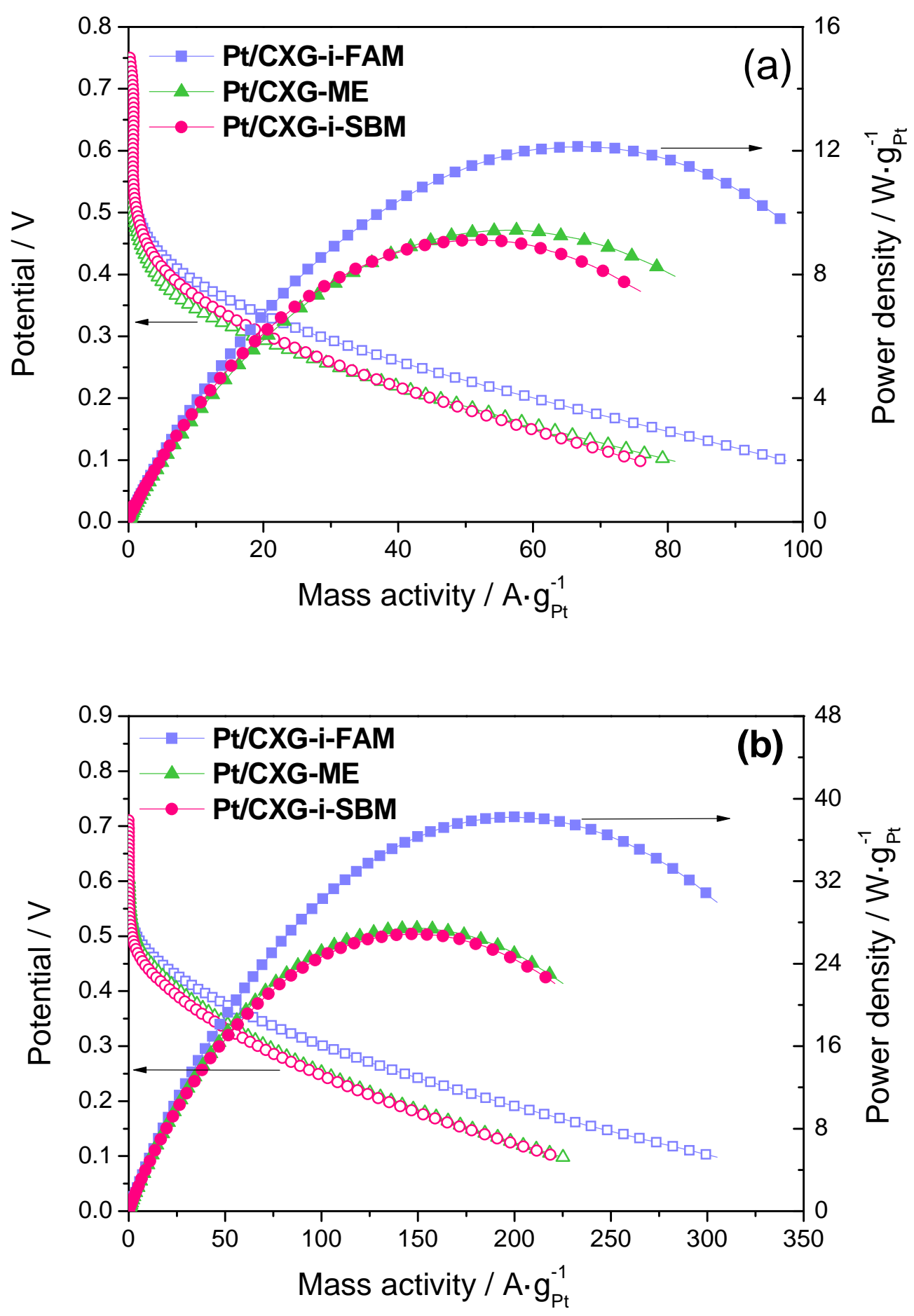
Submitted, accepted and published in Applied Catalysis B: Environmental 147 (2014) 947-957. Post-print of:

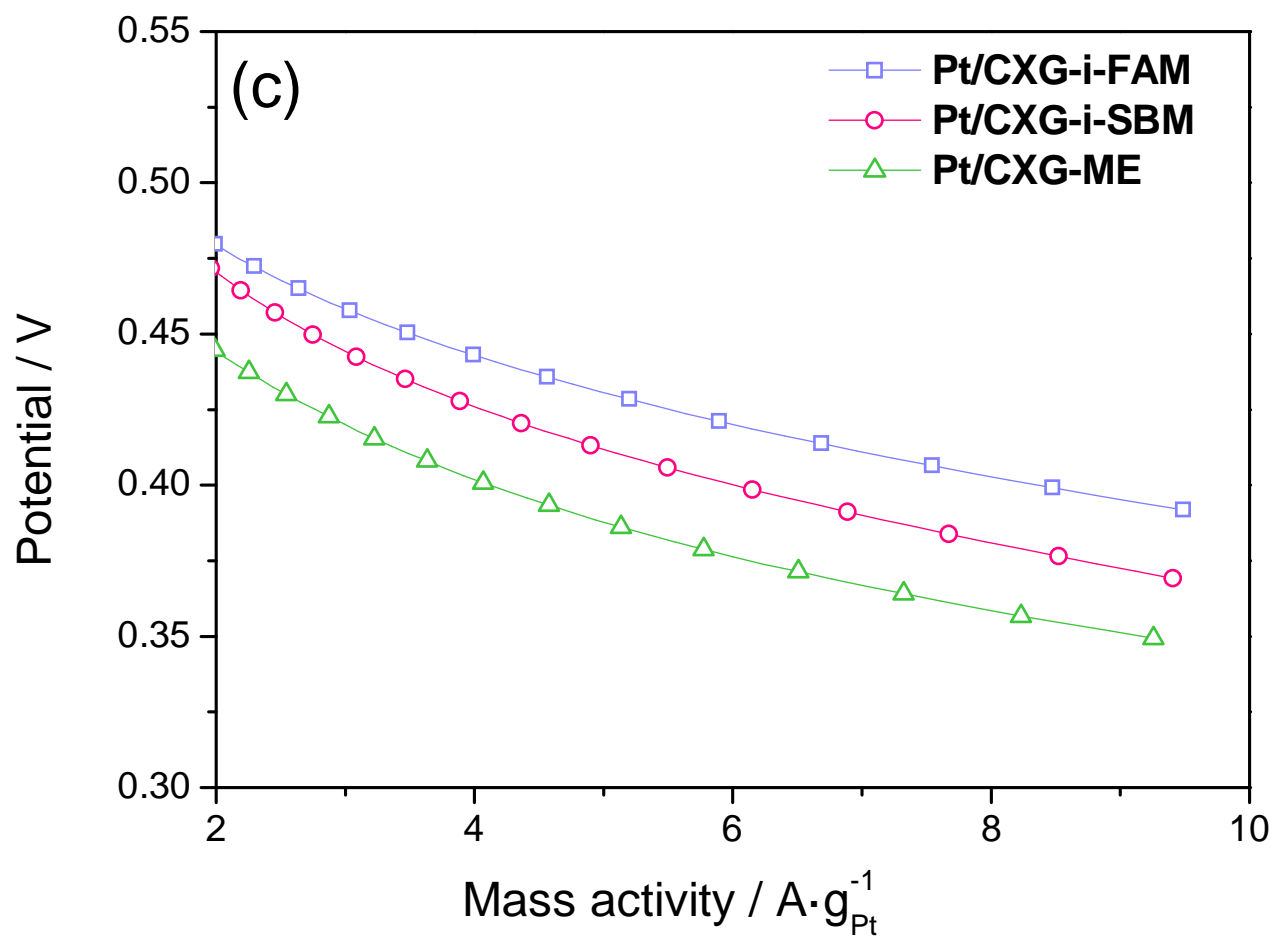


Submitted, accepted and published in Applied Catalysis B: Environmental 147 (2014) 947-957. Post-print of:

Figure 6
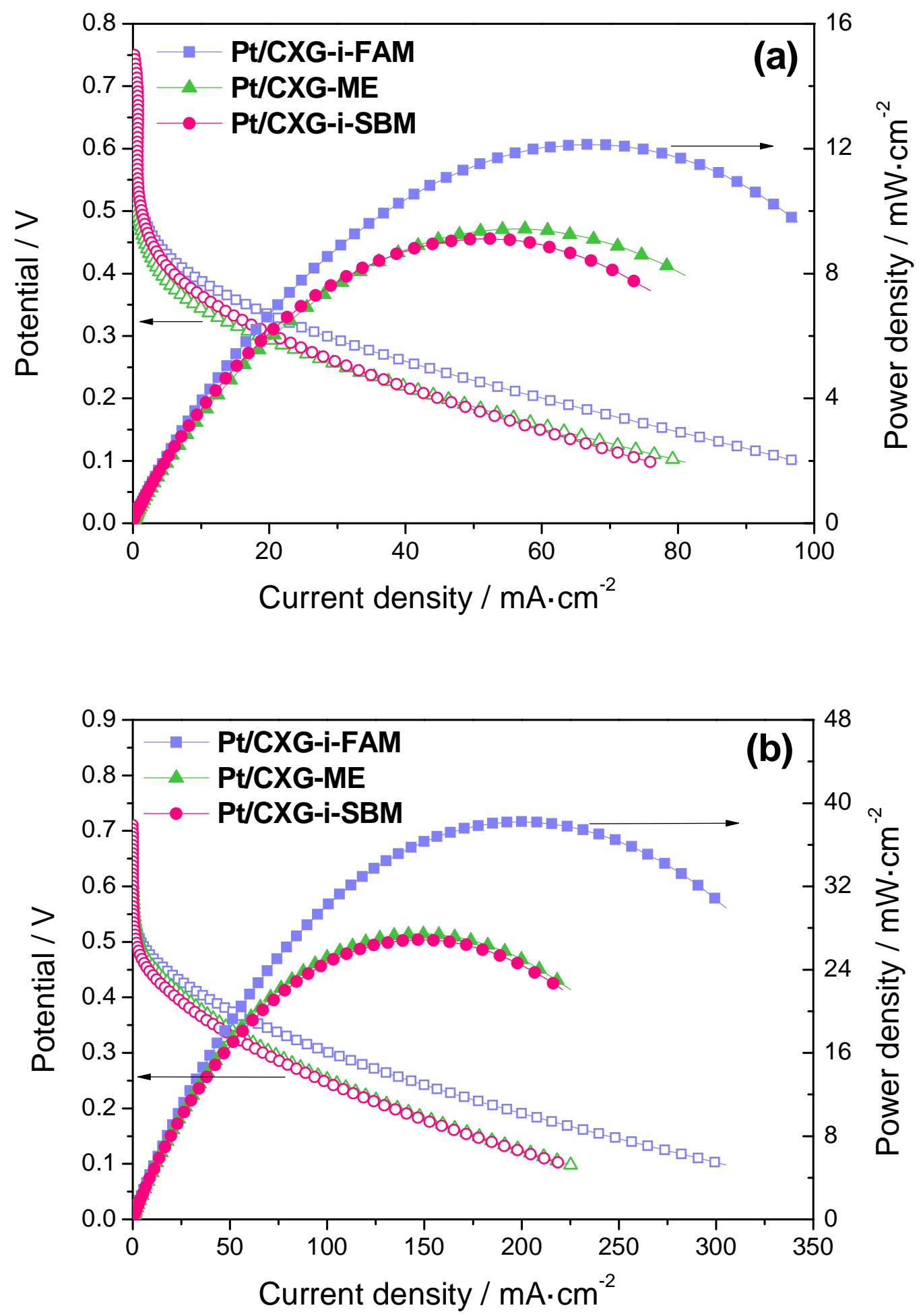
Submitted, accepted and published in Applied Catalysis B: Environmental 147 (2014) 947-957. Post-print of:

Figure 7.
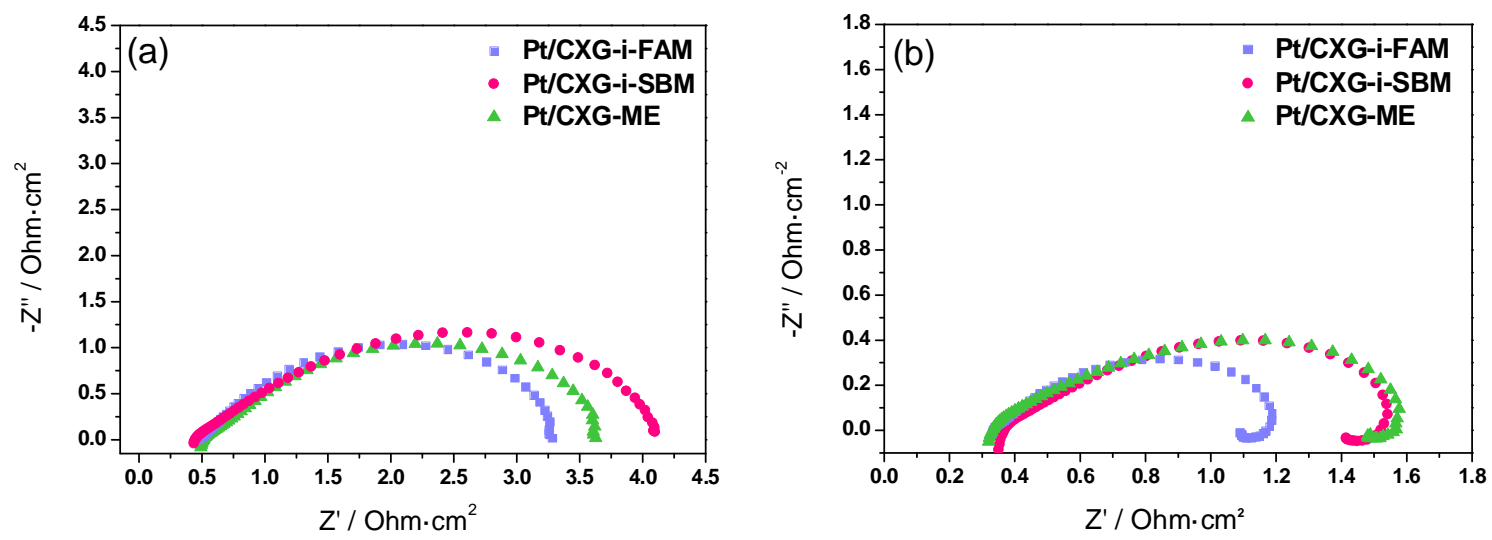
Submitted, accepted and published in Applied Catalysis B: Environmental 147 (2014) 947-957. Post-print of:

Figure 8.
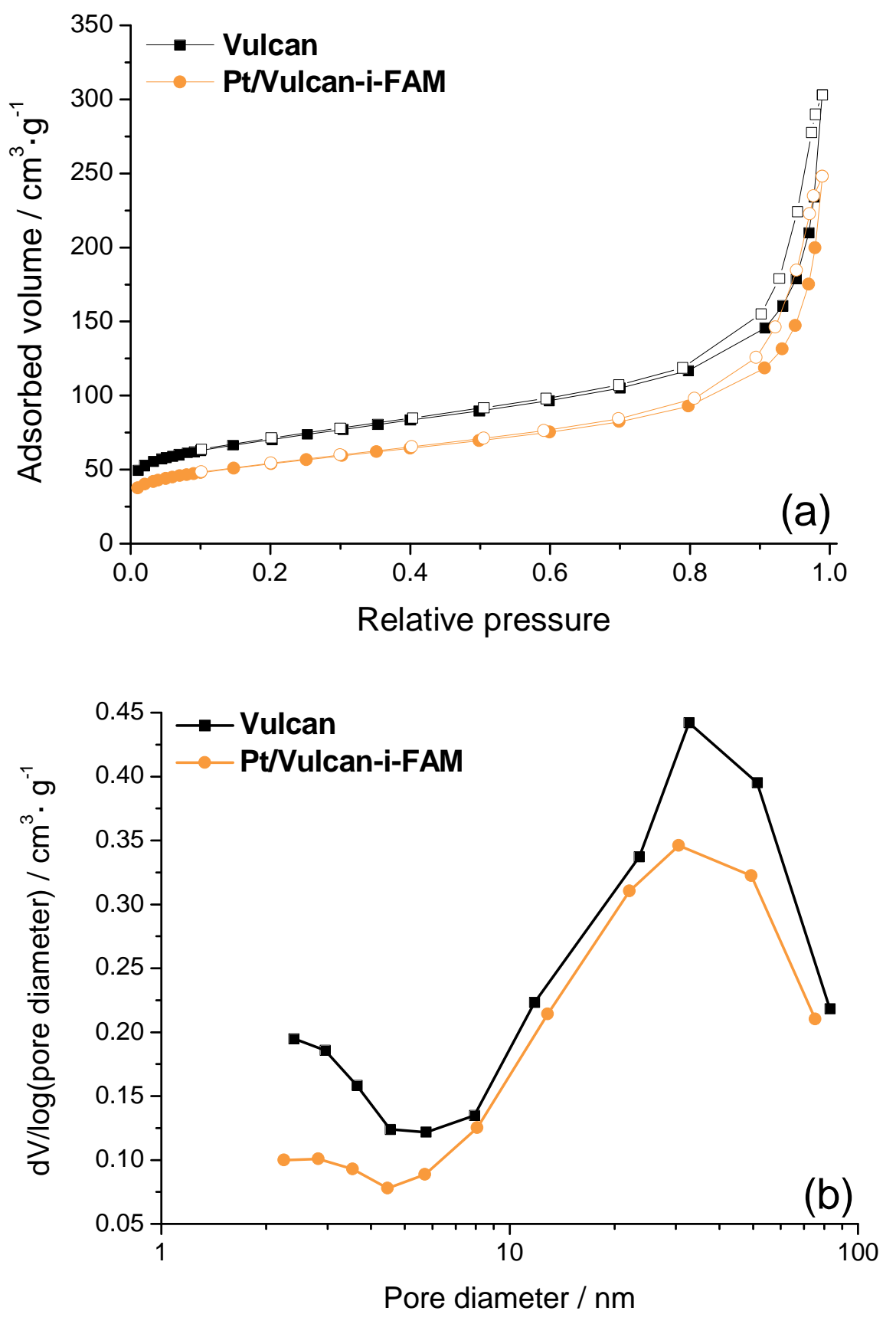
Submitted, accepted and published in Applied Catalysis B: Environmental 147 (2014) 947-957. Post-print of:

Figure 9.

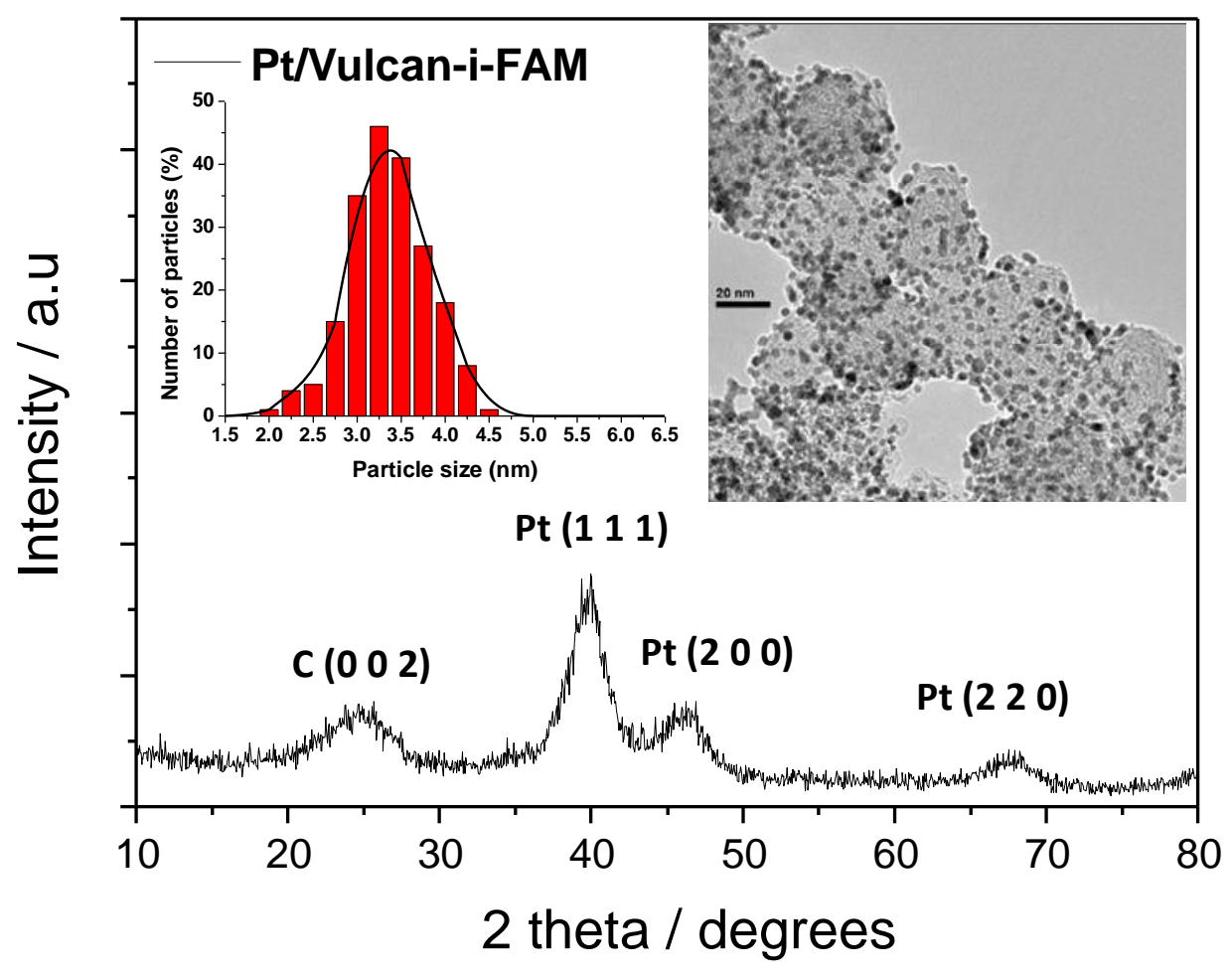


Submitted, accepted and published in Applied Catalysis B: Environmental 147 (2014) 947-957. Post-print of:

Figure 10 .
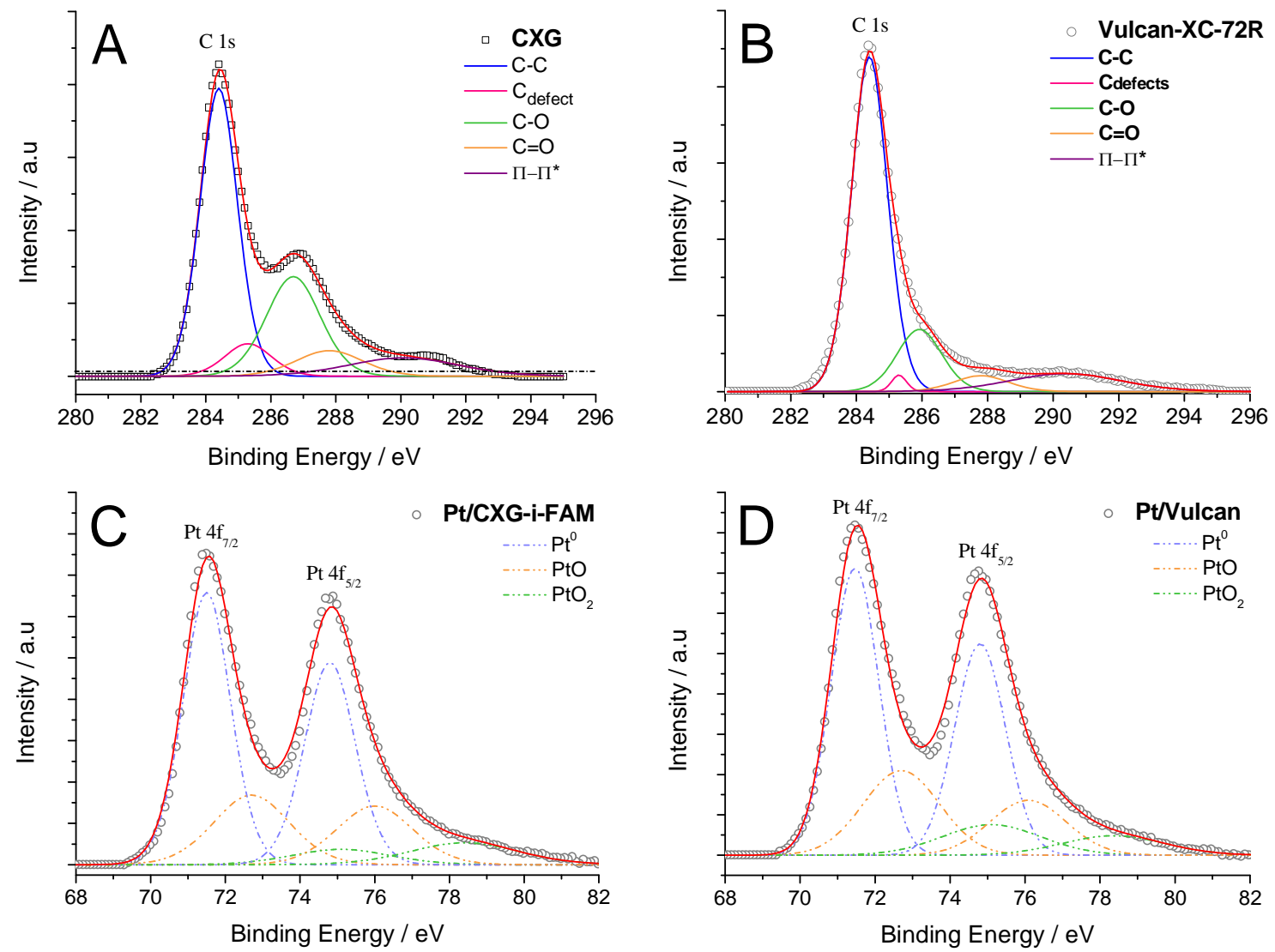
Submitted, accepted and published in Applied Catalysis B: Environmental 147 (2014) 947-957. Post-print of:

Figure 11.
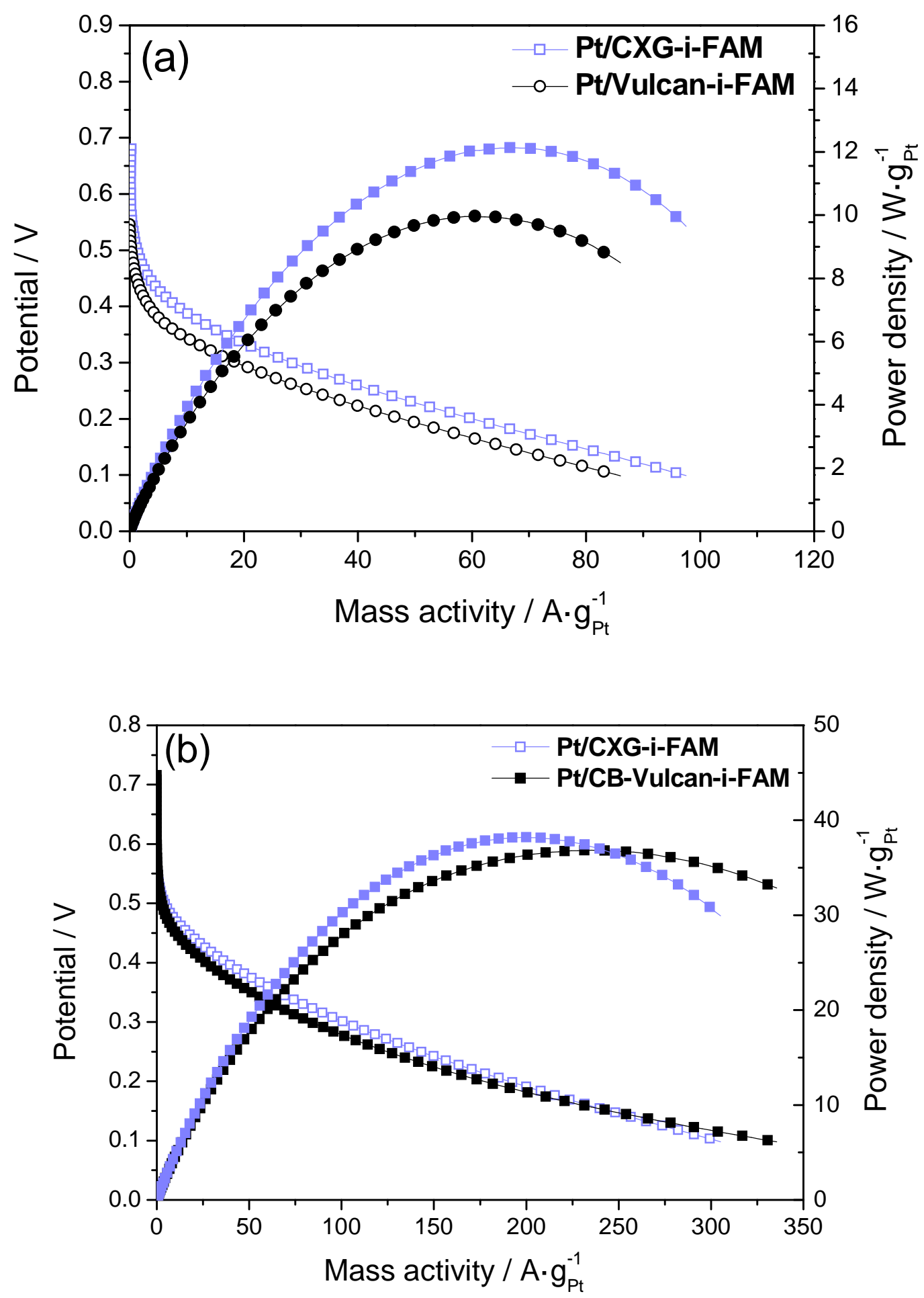
Submitted, accepted and published in Applied Catalysis B: Environmental 147 (2014) 947-957. Post-print of:

Figure 12.
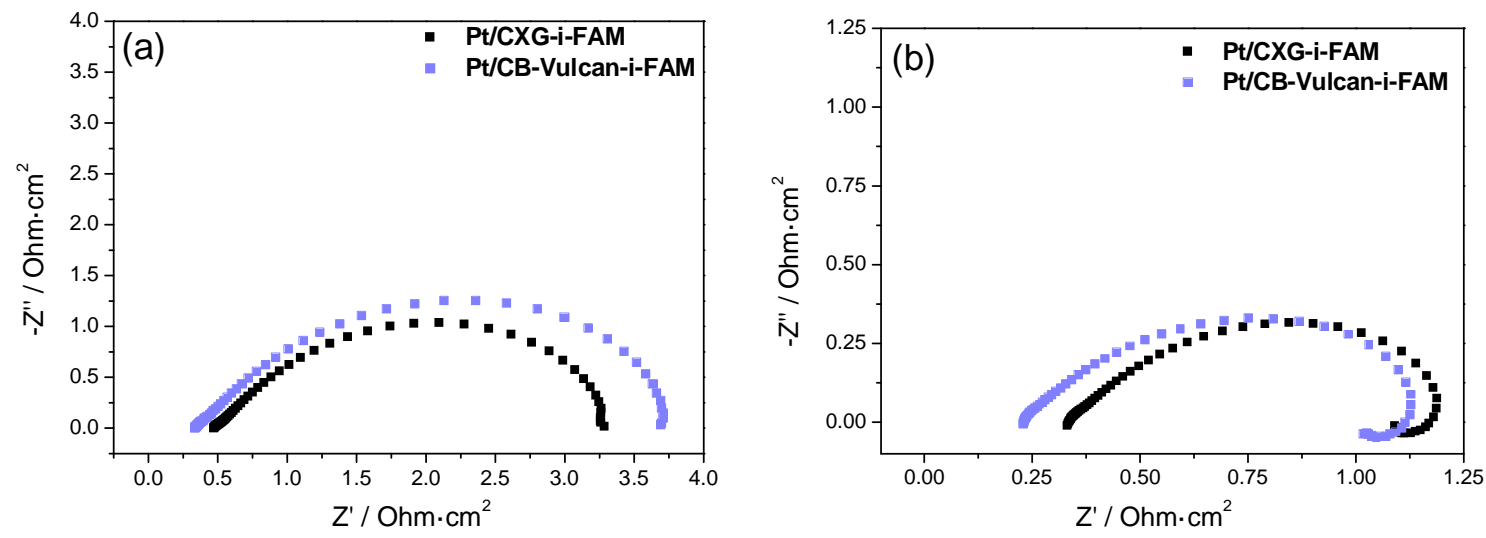
Submitted, accepted and published in Applied Catalysis B: Environmental 147 (2014) 947-957. Post-print of:

Figure 13.
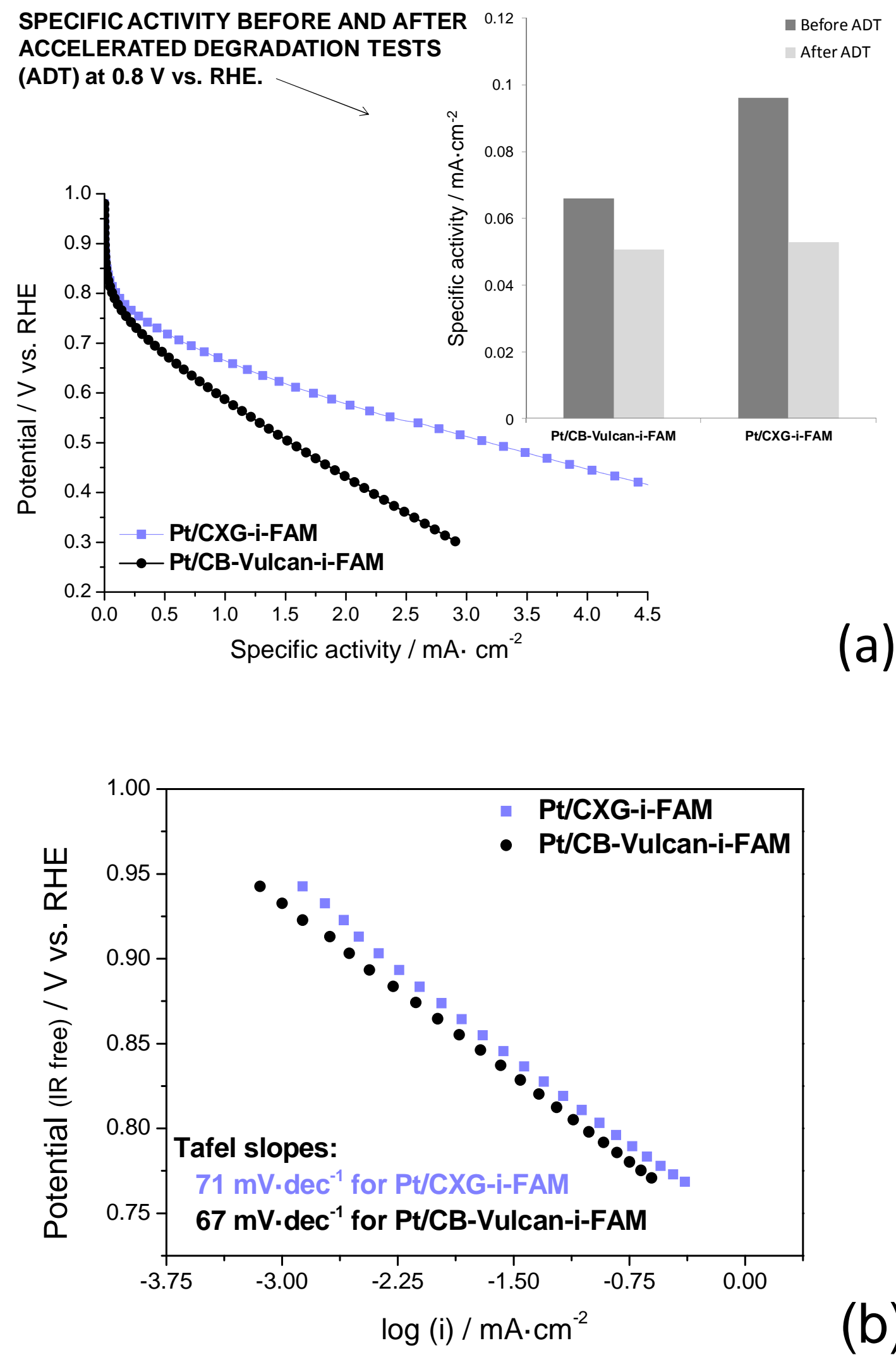

(b) 
Submitted, accepted and published in Applied Catalysis B: Environmental 147 (2014) 947-957. Post-print of:

Table 1. Surface area $\left(\mathrm{S}_{\mathrm{BET}}\right)$, total $\left(\mathrm{V}_{\text {pore }}\right)$, micropore $\left(\mathrm{V}_{\text {micro }}\right)$ and mesopore $\left(\mathrm{V}_{\text {meso }}\right)$ pore volumes, as well as average pore size, determined for the carbon xerogel and the Ptcatalysts.

\begin{tabular}{l|ccccc}
\hline Sample & $\begin{array}{c}\mathbf{S}_{\text {BET }} \\
\left(\mathrm{m}^{2} / \mathrm{g}\right)\end{array}$ & $\begin{array}{c}\mathbf{V}_{\text {pore }} \\
\left(\mathrm{cm}^{3} / \mathrm{g}\right)\end{array}$ & $\begin{array}{c}\mathbf{V}_{\text {micro }} \\
\left(\mathrm{cm}^{3} / \mathrm{g}\right)\end{array}$ & $\begin{array}{c}\mathbf{V}_{\text {meso }} \\
\left(\mathrm{cm}^{3} / \mathrm{g}\right)\end{array}$ & $\begin{array}{c}\text { Av. pore size } \\
(\mathrm{nm})\end{array}$ \\
\hline CXG & 528 & 1.79 & 0.15 & 1.64 & 23.4 \\
Pt/CXG-i-SBM & 389 & 1.33 & 0.13 & 1.20 & 24.4 \\
Pt/CXG-i-FAM & 380 & 1.08 & 0.14 & 0.94 & 23.5 \\
Pt/CXG-ME & 129 & 0.53 & 0.00 & 0.52 & 17.1 \\
\hline
\end{tabular}


Submitted, accepted and published in Applied Catalysis B: Environmental 147 (2014) 947-957. Post-print of:

Table 2. Crystal sizes and Pt load as determined from XRD and ICP for the different catalysts prepared.

\begin{tabular}{lcc}
\hline Catalyst & Crystal size (nm) & Pt load (\% wt.) \\
\hline Pt/CXG-i-SBM & 4.2 & 20.2 \\
Pt/CXG-i-FAM & 3.6 & 17.9 \\
Pt/CXG-ME & 3.9 & 17.1 \\
\hline
\end{tabular}


Submitted, accepted and published in Applied Catalysis B: Environmental 147 (2014) 947-957. Post-print of:

Table 3. Pt chemical state as determined from XPS characterization for the different catalysts prepared.

\begin{tabular}{|c|c|c|c|c|}
\hline \multirow{2}{*}{ Sample } & \multicolumn{4}{|c|}{$\operatorname{Pt} \mathbf{4 f _ { 7 / 2 }}$} \\
\hline & Species & B.E. $(e V)$ & $F W H M(e V)$ & Intensity (\%) \\
\hline \multirow{3}{*}{ Pt/CXG-i-SBM } & $P t$ & 71.4 & 1.5 & 63.3 \\
\hline & $\mathrm{PtO}$ & 72.7 & 2.4 & 26.6 \\
\hline & $\mathrm{PtO}_{2}$ & 75.1 & 3.1 & 10.1 \\
\hline \multirow{3}{*}{ Pt/CXG-i-FAM } & $P t$ & 71.5 & 1.5 & 65.6 \\
\hline & $\mathrm{PtO}$ & 72.7 & 2.4 & 26.8 \\
\hline & $\mathrm{PtO}_{2}$ & 75.1 & 3.1 & 7.6 \\
\hline \multirow{3}{*}{ Pt/CXG-ME } & $P t$ & 71.1 & 1.6 & 60.5 \\
\hline & $\mathrm{PtO}$ & 72.5 & 2.5 & 24.1 \\
\hline & $\mathrm{PtO}_{2}$ & 74.1 & 3.1 & 15.3 \\
\hline
\end{tabular}


Submitted, accepted and published in Applied Catalysis B: Environmental 147 (2014) 947-957. Post-print of:

Table 4. Textural properties determined for the commercial support and the Pt-catalyst synthesized by impregnation and reduction with formic acid.

\begin{tabular}{l|ccccc}
\hline Catalyst & $\begin{array}{c}\mathbf{S}_{\text {BET }} \\
\left(\mathrm{m}^{2} / \mathrm{g}\right)\end{array}$ & $\begin{array}{c}\mathbf{V}_{\text {pore }} \\
\left(\mathrm{cm}^{3} / \mathrm{g}\right)\end{array}$ & $\begin{array}{c}\mathbf{V}_{\text {micro }} \\
\left(\mathrm{cm}^{3} / \mathrm{g}\right)\end{array}$ & $\begin{array}{c}\mathbf{V}_{\text {meso }} \\
\left(\mathrm{cm}^{3} / \mathrm{g}\right)\end{array}$ & $\begin{array}{c}\text { Av. pore size } \\
(\mathrm{nm})\end{array}$ \\
\hline Vulcan & 224 & 0.47 & 0.04 & 0.46 & 11.0 \\
Pt/Vulcan-i-FAM & 173 & 0.38 & 0.03 & 0.35 & 11.9 \\
\hline
\end{tabular}


Submitted, accepted and published in Applied Catalysis B: Environmental 147 (2014) 947-957. Post-print of:

Table 5. Crystal sizes and Pt load as determined from XRD and ICP for the catalysts prepared by impregnation and reduction with formic acid.

\begin{tabular}{|c|c|c|c|c|c|c|}
\hline \multirow[b]{2}{*}{ Catalysts } & \multirow{2}{*}{$\begin{array}{c}\text { Crystal } \\
\text { size } \\
(n m)\end{array}$} & \multirow[b]{2}{*}{$\begin{array}{l}\text { Pt load } \\
(\% w t .)\end{array}$} & Species & $P t^{0}$ & $\mathrm{Pt}^{2+}$ & $P t^{4+}$ \\
\hline & & & $\begin{array}{c}\text { Binding } \\
\text { energies }(\mathrm{eV})\end{array}$ & 71.5 & 72.7 & 75.1 \\
\hline Pt/CXG-i-FAM & 3.6 & 17.9 & Intong & 65.6 & 26.8 & 7.6 \\
\hline Pt/Vulcan-i-FAM & 3.4 & 16.7 & Intensity ( $\%$ at) & 61.0 & 26.6 & 12.4 \\
\hline
\end{tabular}

